This item was submitted to Loughborough's Research Repository by the author.

Items in Figshare are protected by copyright, with all rights reserved, unless otherwise indicated.

\title{
Institutional investors and international investments in emerging economy firms: A behavioral risk perspective
}

PLEASE CITE THE PUBLISHED VERSION

https://doi.org/10.1016/j.jwb.2018.12.002

PUBLISHER

(C) Elsevier

VERSION

AM (Accepted Manuscript)

\section{PUBLISHER STATEMENT}

This paper was accepted for publication in the journal Journal of World Business and the definitive published version is available at https://doi.org/10.1016/j.jwb.2018.12.002

\section{LICENCE}

CC BY-NC-ND 4.0

\section{REPOSITORY RECORD}

Panicker, Vidya Sukumara, Sumit Mitra, and Rajesh Srinivas Upadhyayula. 2019. "Institutional Investors and International Investments in Emerging Economy Firms: A Behavioral Risk Perspective”. figshare.

https://hdl.handle.net/2134/36359. 
Institutional Investors and International Investments in Emerging Economy Firms: A Behavioral Risk Perspective

\author{
Vidya Sukumara Panicker \\ Lecturer in International Business \\ School of Business and Economics \\ Loughborough University \\ Loughborough, United Kingdom \\ v.s.panicker@lboro.ac.uk \\ vidya.s.panicker@gmail.com \\ Sumit Mitra \\ Professor \\ Strategic management area \\ Indian Institute of Management \\ Kozhikode, Kerala, India \\ smitra@iimk.ac.in \\ Rajesh Srinivas Upadhyayula \\ Associate Professor \\ Strategic management area \\ Indian Institute of Management \\ Kozhikode, Kerala, India \\ rajesh@iimk.ac.in
}




\title{
Institutional Investors and International Investments in Emerging Economy Firms: A Behavioral Risk Perspective
}

\begin{abstract}
While the extant literature has examined the influence of controlling and non-controlling principals on the internationalization decisions of emerging market firms, heterogeneity among non-controlling principals is largely ignored. The risk characteristics of different groups of owners, shaped by their institutional environments, could contribute to the differences in their preferences for firm internationalization. In this paper, we draw insights from institutional theory and behavioral risk perspective to examine the risk propensities and risk perceptions of various non-controlling principals, such as pressure-resistant (FIIs and mutual funds) and pressuresensitive (banks, insurance companies and lending institutions) institutional investors. Empirical results from a sample of 2364 unique Indian firms during the 2005-2014 time-period show that, after controlling for firm-level resources and capabilities identified in prior literature, the ownership share of different types of institutional investors is associated with firms' international investments differently. While pressure-sensitive institutional investors, such as banks and insurance companies, are not supportive of foreign investments by firms, pressure-resistant institutional investors, such as FIIs and mutual funds, are supportive of this strategic decision. Furthermore, our results show that the family ownership in a firm (measured in terms of family shareholding) further lowers the preference of pressure sensitive institutional investors for internationalization, whereas family ownership positively moderates the pressure resistant investors towards internationalization.
\end{abstract}

Keywords: Internationalization, Ownership structure, Family ownership, Institutional investors, Emerging Markets, Behavioral risk 


\section{Introduction}

Extant literature recognizes the importance of principal-principal conflict in the emerging economies (Dharwadkar, George \& Brandes, 2000; Khanna \& Palepu, 2000) with studies finding that institutional ownership, and foreign institutional investors in particular, have a positive impact on the internationalization of emerging market firms (Bhaumik, Driffield \& Pal, 2010; Gaur \& Kumar, 2009; Singh \& Gaur, 2013). In such studies, it is assumed that the risk characteristics of family owners and other investors are similar or aligned.

In the context of developed economies, however, studies from an agency perspective show that the different categories of institutional investor (viz., pressure-sensitive institutional investors and pressure-resistant institutional investors) have varying degrees of influence on the internationalization of firms (e.g. Ferreira \& Matos, 2008; Kochhar \& David, 1996). While the influence of pressure-sensitive investors, such as banks and insurance companies, on firm level strategy was found to be passive and aligned with the interests of the agent (i.e., the manager), it was found that pressure-resistant investors (such as foreign institutional investors and mutual funds) discipline managers in the developed economies. These studies assume differential but stable risk preferences for the actors, in that agents are deemed to be risk averse and principals are deemed considered to be risk neutral (Wiseman \& Gomez-Mejia, 1998). However, Wiseman \& Gomez-Mejia (1998) questioned this premise of stable risk preferences and formulated the behavioral agency theory of managerial risk taking, which explains executive risk-taking behavior in the context of the developed economies. Further, other studies also recommend widening the scope of traditional agency theory by extending the economists' formal concept of risk to incorporate a more behavioral perspective (Tirole, 2002). More recent studies use the behavioral risk perspective to show that the managers' risk preferences affect the 
internationalization decision of emerging economy firms as well (e.g. Buckley, Clegg, Chen \& Voss, 2018; Clarke \& Leisch, 2017). It has been noted that decision making in most emerging economy firms is dominated by large controlling shareholders (e.g., family) rather than by the managers (Young et al., 2008) but the existing literature in this context does not examine the diverse risk preferences of the different categories of owners towards internationalization, whether they be family owners, pressure-sensitive institutional investors, or pressure-resistant institutional investors. This study fills that gap by examining the association between these three categories of owners and the internationalization of firms. Drawing on the institutional perspective, we add to the behavioral risk theory by arguing that the risk characteristics of the different categories of owner are shaped differently in the emerging markets compared to the developed markets, consequently affecting strategic outcomes such as internationalization.

We test our model through a panel of 7591 firm years (2364 unique firms) of Indian firms over a 10-year period (2005-2014), using Tobit regression estimation techniques. Our findings demonstrate how the different categories of institutional investors affect the governance of emerging economy firms. Consistent with previous studies (e.g. Bhaumik, Driffield \& Pal, 2010; Ray, Mondal \& Ramachandran, 2018), we find that family ownership has a negative association with the internationalization of emerging economy firms. Our results also highlight that pressuresensitive institutional investors and pressure-resistant institutional investors are significant determinants of internationalization, albeit in different ways. We find that pressure-sensitive investors, who have hereto been consistently identified merely as passive monitors in the developed markets, are actually actively engaged in the strategic decision-making of emerging market firms. Owners such as domestic banks and insurance companies with limited experience of international operations have a higher perception of risk regarding internationalization, and 
dissuade firms from expanding overseas. Pressure-resistant investors, on the other hand, owing to their low perception of risk derived from their familiarity with the international markets gained from their extensive international operations, support the internationalization of firms. The interaction of institutional investors with the controlling family ownership structure of a firm also reveals interesting results. While pressure-sensitive institutions refrain from getting involved in international investments with family-controlled firms, we find that pressure-resistant institutions support international investments in such firms due to the risk-related advantages offered by family ownership. Our findings contribute to the emerging market literature in three ways. Firstly, we contribute to the emerging market internationalization literature by highlighting the micro-foundational role of owner-decision makers' risk perceptions, as well as by showing how the institutional context shapes these risk perceptions. Secondly, we extend behavioral risk theory by drawing key insights as to how the institutional lens shapes the risk perceptions of different categories of institutional investor and affects their internationalization decisions. Thirdly, we contribute to the governance of emerging market firms by showing how the extent of concentrated controlling ownership (especially family ownership) modifies the risk perceptions of different categories of institutional investor.

\section{Theory and hypotheses}

\subsection{Ownership categories and strategic preferences of emerging market firms}

The characteristics of the owners of a firm impact the firm's risk-taking behavior (Burkart, Gromb \& Panunzi, 1997). For instance, Gomez Mejia et al (2007) show that family owners do not take into consideration the likely financial gains alone when making decisions concerning the firm. They will often also consider issues like protection against loss of socioemotional wealth and the perpetuation of a family dynasty, and these considerations are 
instrumental in shaping their risk perceptions. Since family control (which often coincides with business group affiliation) is the most ubiquitous form of ownership in the emerging markets (Khanna \& Palepu, 1997), the theoretical implications of family ownership in these markets require special attention. Concentration of ownership with families results in an agency problem, which is distinctly different from that seen in the developed economies where the agency problem exists in the form of a divergence of interest between the principals of a firm (owners) and its agents (managers) (Jensen \& Meckling, 1976; Young et al, 2008). The emerging economies on the other hand face a secondary agency issue, namely a principal-principal agency problem (Dharwadkar et al., 2000; Morck, Wolfenzon \& Yeung, 2005; Young et al., 2008). The findings from the emerging economy context are equivocal on the relationship between family ownership and internationalization. While some (e.g. Chittoor, Aulakh \& Ray, 2015; Singh \& Gaur, 2013) find a positive association, others (e.g. Bhaumik, Driffield \& Pal, 2010; Ray, Mondal \& Ramachandran, 2018) find a negative relation between family ownership and international investments. Studies also show that institutional ownership in general (e.g. Singh \& Delios, 2017; Singh \& Gaur, 2013) and foreign institutional ownership in particular (e.g. Bhaumik, Driffield \& Pal, 2010), are associated positively with the internationalization of investee firms. These studies, however, do not distinguish between the risk preferences of the various categories of investors. This is irrespective of the fact that in the developed economy context, a degree of understanding about the heterogeneity of the strategic preferences of various types of institutional investor has already been established (e.g. George, Wiklund \& Zahra, 2005; Tihanyi et al., 2003). For instance, Tihanyi et al. (2003) identify the differences in the internationalization preferences of investment funds versus pension funds in their investee firms. Others (e.g. Brickley, Lease \& Smith, 1988; Ferreira \& Matos, 2008) base their study on whether 
institutional investors can be classified as pressure-sensitive or pressure-resistant. As per this classification, investors who have existing business relations with firms are termed as pressuresensitive. Such institutions (e.g. banks, insurance companies, and lending institutions) are dependent on these firms for a large part of their income, both in the form of interest income (derived from the loans they offer to firms) and fee income (remuneration for meeting firms' financial needs) (Ramaswamy, Li \& Veliyath, 2002). Therefore, for fear of jeopardizing the existing and potential business relations with the firm, pressure-sensitive institutional investors in the developed economies are seen to abide by the decisions the managers take, making the investors passive monitors of the firm (Ferreira \& Matos, 2008; Kochhar \& David, 1996). Conversely, pressure-resistant institutional investors (e.g., mutual funds, pension funds, and other professional investors) are associated with the firm only as secondary market investors; thus, when they are discontented, they voice their opinions or even exit the firm, enabling them to act as strong monitors (e.g. Muniandy, Tanewski \& Johl, 2016; Tihanyi et al, 2003).

Studies that draw on agency theory to explain the impact of ownership preferences on firm strategies assume stable risk preferences for principals and agents (Wiseman \& GomezMejia,1998; Pepper \& Gore, 2015). However, the stable risk preferences led agency theory cannot explain the differential impact of agent/principal on firm performance (Kanheman \& Tversky, 1979). Agency theory also underplays the role that the decision context plays on the risk-taking behaviour of decision makers (Wiseman \& Catanach, 1997). Therefore, researchers argue that the agency theory formulation of risk has been "restrictive and naïve" (Wiseman \& Gomez-Mejia, 1998: 133). Consequently, Wiseman \& Gomez-Mejia (1998) formulated the behavioral agency theory of managerial risk taking, which explains executive risk-taking behavior in the context of a developed economy. 


\subsection{The behavioral risk perspective of decision-making}

Sitkin \& Pablo (1992) argue that the role of risk in organizations has gained increased importance as the consequences of risky decisions have become more visible. They integrate different streams of research on risk taking, and propose that there are two key mediating mechanisms through which a variety of variables act to influence individual risk behavior in organizational settings - Risk propensity and Risk perception. Risk propensity is defined as the cumulative general tendency of the individual to either take or avoid risks, and also affects how a decision maker evaluates risk and decides which risks are acceptable (Pablo et al., 1996; Sitkin \& Pablo, 1992). The risk propensity of an individual is determined by their risk preferences (achievement orientation), inertia (past behavior), and outcome history (the success rate of risky behavior). Risk perception is defined as a decision maker's assessment of the risk inherent in a specific situation. The decision making assessment comprises first the labelling of the situation, then the estimates of how extensive and controllable the risks are, and finally the level of confidence in those estimates. The risk propensity of individuals contributes to their risk perceptions, along with, inter alia, problem framing (negative vs. positive), composition of top management teams, and social pressures. While the risk propensity of firm owners is very individualistic, risk perception is more contextual in nature, including as it does the degree of familiarity with the problem domain. In the following section, we explain the fundamental role of the institutional environment in shaping the behavioral risk perceptions of different categories of owner. 


\subsection{The influence of institutional context on the risk perception of institutional ownership}

The preferences of institutional investors in an emerging economy context are not necessarily akin to those of investors in a developed economy. One of the reasons for this is that firms in the emerging economies are often dominated by controlling principals (such as a family or business group). Principal-principal problems between such investors, together with differences in the institutional context, could modify the risk preferences and consequently the behavior of the non-controlling institutional investors (Young et al., 2008). The institutional environment is found to be material in shaping the perceived uncertainties and risk associated with transactions in the emerging markets (Demirbag, McGuiness \& Altay, 2010). The highly divergent arrays of institutional features, unique to the many different national contexts (North, 1990), may cognitively affect perceptions of risk among its actors in very different ways (Makhija \& Stewart, 2002). Specifically, the institutional framework of a country can change the perceived riskiness of decision situations by affecting the nature and availability of information related to the decision, and the perceived consequences of it (Makhija \& Stewart, 2002). Recent studies argue that risky internationalization decisions of a firm primarily depend on the focal context of the decision makers, constituted by their home-country institutional environment (Buckley et al., 2018; Clarke \& Leisch, 2017). Studies that adopt the behavioral agency perspective explain the strategic investments of a firm as being a function of the risk characteristics of the individuals who are involved in decision-making, where those decisionmakers perceive a sense of control over the risk in question (e.g. Buckley et al., 2018; Chittoor, Aulakh \& Ray, 2015; Clarke \& Leisch, 2017; George, Chattopadhyay, Sitkin \& Barden 2006). In our study, we use the institutional lens to educate and extend the behavioral risk perspective, explaining how the risk behavior of different categories of owner (e.g., family owners or 
institutional investors) of emerging market firms is shaped. As an extension, we also study how the preference of institutional investors towards internationalization varies with the extent of family ownership of the firm.

\subsection{Family ownership and international investments}

Family ownership is an outcome of the institutional context of the emerging markets, which lack intermediary firms, regulatory systems, and contract enforcing mechanisms (Fogel, 2006; La Porta et al.,1999). The literature on risk perception in family firms is equivocal. One stream of research argues that the owners of a family firm will have a higher risk propensity where the risks are accompanied by a commensurately high potential for increased returns on investment (e.g. Carpenter et al., 2003). This can be seen in the emerging economies (Gaur \& Kumar, 2009) that witness bold moves, such as foreign expansion.

However, others have identified risk-averse behavior in family owners due to reasons such as fear of performance variability (Naldi et al., 2007), fear of losing family wealth that has been created over a long period of time (Sharma et al., 1997; Ward, 1997; Schulze, Lubatkin, \& Dino, 2002), and fear of losing control (Zhang \& Ma, 2009). Gomez-Mejia et al. (2007) argue that family owners have a low risk propensity, which leads to less exploration of innovative ideas (Chrisman, Chua \& Sharma, 2005), sticking to past patterns of resource allocation (Gilbert 2005; Guillén 2002; Schreyoegg \& Kliesch-Eberl 2007), and preserving family traditions (Dyer, 1984).

In the emerging markets, domestic family firms derive benefits due to institutional voids, government support, or a combination of other factors such as market failure and the absence of market intermediaries (Khanna \& Palepu, 1997). As the environment moves in a more international direction, these institutional characteristics cease to be competitive advantages for 
the firms and may even be the source of their demise (Gaur \& Kumar, 2009). Lacking the skills required for attracting foreign investment, such firms need, however reluctantly, to transfer considerable decision-making power to outside professionals (Johanson \& Vahlne, 1977; Zhang \& Ma, 2009). Therefore, from a behavioral risk perspective, family owners have a lower propensity for taking risks, while also maintaining a higher perception of the risk involved in international investments. Therefore, in line with Bhaumik, Driffield \& Pal (2010) and Ray, Mondal \& Ramachandran (2018), we hypothesize:

Hypothesis 1: In an emerging economy, family ownership is negatively associated with the level of a firm's international investments.

\subsection{Institutional shareholdings and international investments}

Extant literature has already demonstrated the differences between categories of institutional investors towards internationalization decisions (e.g. Lien et al., 2005; Tihanyi et al., 2003). In this study we analyze the risk propensity and risk perception for pressure-sensitive institutional investors (PSIIs) and pressure-resistant institutional investors (PRIIs), and their implications on the internationalization of emerging economy firms.

Pressure-sensitive institutional investors (PSII): Though the studies in developed country contexts have identified PSIIs, such as banks and insurance companies, to be passive monitors in firms (e.g. Ferreira \& Matos, 2008; Muniandy, Tanewski \& Johl, 2016), we argue that this relationship will not hold true in the context of the emerging economies. Unlike developed economy firms, firms in the emerging economies rely mostly on external financing through debt, with PSIIs such as banks and insurance companies serving as their major sources of capital (Dwivedi \& Jain, 2005; World Bank, 2005). Most of the PSIIs in India are therefore simultaneously shareholders as well as sizeable creditors (Dwivedi \& Jain, 2005), with the 
creditor relationship strengthening their role as equity holders (Sarkar \& Sarkar, 2000) ${ }^{1}$. In addition, it is common in India for there to be institutional representation on the board of a firm in the form of a nominee director ${ }^{2}$ who, given their institution's significant lending to the firm, primarily have the creditors' interests in mind (Nachane, Ghosh \& Ray, 2005). Further, PSIIs in the emerging economies have a comparative advantage when influencing firm-level decisionmaking due to the availability of inside information (Gillan \& Starks, 2003). Thus, a PSII in the Indian context is an institution that has the ability to assiduously monitor firm-level actions, while exerting control on the firm's strategic decision-making process (Sarkar, Sarkar \& Sen, 2008). Further, Aguilera \& Jackson (2003) identify that the multiplexity (overlapping) of relationships between entities such as banks and firms, force an increased commitment by the former by making it costlier for them to exit the firm. Therefore, a lending PSII will safeguard its own interest of liability by extending its monitoring of the firm's investment decisions (Pan \& Tian, 2015). This leads to the PSII becoming strategically involved in the activities of a firm. Therefore, in line with behavioral risk theory, it could be argued that as monitors, the investment choices of PSIIs would depend on their overall risk propensity and their specific perception of risks in their international investment decisions. In their capacity as investors, PSIIs would not automatically oppose a firm from being involved in high risk/high return activities. As creditors, however, the institutions would prefer that the firm engage in conventional, risk-free strategies that ensure a steady flow of interest income and the lowest possibility of default on loan repayments (Firth, Lin \& Wong, 2008). Hence, the creditor-investor duality is instrumental in shaping PSIIs into players with low risk propensities.

\footnotetext{
${ }^{1}$ For instance, ICICI bank is the major creditor of the Jaypee group-owned real estate company, Jaypee Infratech, and the bank also owns about $1 \%$ of shares of the group as at March 2016. Jaypee Infratech also has significant debt with IDBI bank, while the bank holds $2 \%$ of their shares and has a nominee representative on the board of directors

${ }^{2}$ While being an equity holder does not entitle a financial institution to nominate a director to the board, its dual role as a lending institution guarantees it a board nomination as a part of the credit agreement (Sarkar \& Sarkar, 2000), and it is under this arrangement that most PSIIs in India have their representatives on the company board.
} 
Further, Iacoviello \& Minetti (2006) suggest that local banks in the developing economies do not have sound assessment practices nor do they hold sufficiently advanced information technologies to be able to evaluate the outcomes of internationalization as effectively as their foreign counterparts, increasing the risk perception of this category of owner. Thus, they dissuade through voting, activism, and dialogue with management, their investee firms from internationalizing.

Hypothesis 2: In an emerging economy, higher shareholding in a firm by pressuresensitive institutional investors is negatively associated with the level of international investments of the firm.

Pressure-resistant institutional investors (PRII): In India, it is found that PRIIs generally involve themselves with an investee firm through institutional activism, such as by associating with proxy advisory firms and via the prompting of intervention by the Securities and Exchange Board of India (SEBI) and the country's legal systems ${ }^{3}$. As a group of shareholders, a PRII might only have small individual holding, but as a category of investors, PRIIs overall gain power through coordinated action (David, Kochhar \& Levitas, 1998; Ramaswamy, Li \& Veliyath, 2002). Thus, PRIIs monitor the actions of firms by either resorting to investor activism through coordinated action or by disciplining the firm in the form of stock exits.

PRIIs are driven by strong wealth maximization objectives for the potential investors in these funds who closely scrutinize fund performance (Ramaswamy, Li \& Veliyath, 2002). PRIIs therefore welcome internationalization for its potentially positive effects and its rapid returns on shareholder wealth (Tihanyi et al., 2003). But investing internationally is prone to higher risk (Ćirić \& Njegomir, 2011), motivating PRIIs to undertake corporate risk-management in their investee firms through improvements in firm-level governance (Ferreira \& Matos, 2008; Gillan

\footnotetext{
${ }^{3}$ For example: Maruti Suzuki India ltd, Akzo-Nobel India ltd, TCI, UK, and others
} 
\& Starks, 2003). Domestic mutual funds as PRIIs', do sound assessment of local firms giving them a greater understanding of those firms' capacity to undertake risky strategies (Choe, Kho \& Stulz, 2001). Foreign institutional investors (hereafter "FIIs") also classified as PRIIs, since they stand outside the usual domestic social networks (Peng, 2003; Young et al., 2008), are consequently not deterred from acting as strong monitors (Ramaswamy, Li \& Veliayth, 2002). In the emerging economies, foreign investors can be seen to perform a monitoring function while encouraging value-enhancing risk taking (Kim, 2011). FIIs have a better understanding of the associated risks in the international markets because of their experience and expertise, and this lowers their risk perception (Dvorak, 2005; Seasholes, 2000). The higher risk propensity and lower risk perception of PRIIs means that firm internationalization is an attractive option for them (Del Guercio \& Tkac, 2000) and they would therefore be supportive of the internationalization of their investee firms.

Hypothesis 3: In an emerging economy, higher shareholdings by pressure-resistant institutional investors in a firm is positively associated with the firm's level of international investments.

Table 1 summarizes the monitoring mechanism and risk characteristics of different types of institutional investor, and also how they behave with regard to the internationalization strategies of firms.

Insert Table 1 about here

\subsection{Interaction between families and institutional investors}

In the emerging economies, an institutional investor is a buffer between the minority (e.g. individuals and other small shareholders) and majority shareholders (e.g. family, business 
groups, and dominant shareholders), helping to negotiate the uneasy relationship between the two (Hamdani \& Yafeh, 2012). With their large outside shareholdings, such institutional investors are better placed to negotiate with the management of an invested firm and to alleviate principal-principal agency issues by taking on the role of shareholder activist on behalf of the minority shareholders. Banks and other lending institutions gain additional leverage from their dual-role as lender-shareholder (Sarkar \& Sarkar, 2000; Varma, 1997). Therefore the interaction between these two large categories of owner, viz., families as controlling owners and the different categories of institutional investor, could skew the risk perceptions of the strategic decisions of a firm.

In the emerging economies, debt plays a significant role in growth and expansion activities such as internationalization (Dwivedi \& Jain, 2005; World Bank, 2005). PSIIs, such as banks and insurance companies, are primary lenders to firms that are owned by families and business groups, mainly due to the reputational advantages of these firms (Lensink, Molen \& Gangopadhyay, 2003). PSIIs in the emerging economies favor politically connected firms that are associated with strong families or business groups (Khwaja \& Mian, 2011). These familyowned firms hold a large percentage of debt from PSIIs between them, and the debt holding has consistently increased over the last several years (Bahree, 2013). ${ }^{4}$ Due to the important role played by the debt holders, families cannot ignore the preferences and choices of PSIIs. Family owners are found to resist the dilution of their equity stakes in the long run because the value of control rights is generally greater than the gains accrued from selling out shares to equity investors (Filatotchev \& Mickiewicz, 2001). Consequently, family-owned firms that are making capital-intensive strategic decisions, such as internationalization, are more inclined to increase

\footnotetext{
${ }^{4}$ Recent reports show that the top 10 corporate groups in the country owed INR 5,73,682 crores (USD 8600 million) to state-owned banks and financial institutions at the end of March 2016 (Economic Times, 2016).
} 
their debt rather than dilute their holdings so that their socio-emotional wealth is sustained. Hence, pressure-sensitive institutional investors (in their capacity as dual holders) have higher risk perception for family-owned firms compared to non-family-owned firms because of the high levels of debt and increased possibility of default.

Therefore, we argue that the risk perception of a PSII in a family-owned firm would be higher than non-family owned firm due to their stronger role as creditors. Consequently, PSIIs can be expected to be circumspect about the internationalization of family firms.

Hypothesis 4: In an emerging economy, family ownership of a firm strengthens the negative effect of pressure-sensitive institutional investors on the level of international investments of these firms.

PRIIs are inherent risk takers for whom the benefits of internationalization outweigh the risks (Ćirić \& Njegomir, 2011; Del Guercio \& Tkac, 2000). PRIIs are oriented towards stock market based measures of performance and have the requisite incentive to sell their stake if a firm cannot maintain short-term capital market gains (Ramaswamy, Li \& Veliyath, 2002). Consequently, PRII fund managers manage a diversified portfolio. Such investors, who utilize index-type investment strategies that promote overall performance of a stock portfolio rather than individual stock performance, will have limited incentives to be directly involved in monitoring firms (Del Guercio \& Hawkins, 1999; Muniandy, Tanewski \& Johl, 2016), instead preferring to sell shares if performance falls. Thus, being a portfolio investor, a PRII would have no particular preference for a family-owned over a non-family-owned firm, although the internationalization of family-owned firms could offer other risk-related advantages to these investors. For example, the presence of a dominant shareholder in the form of a business group or family fills the institutional voids that are rife in an emerging economy, and helps the 
affiliated firms circumvent the problems arising from a weaker institutional environment (Chang \& Choi, 1988; Khanna \& Palepu, 1997, 2000; Bodnaruk, Massa \& Zeume, 2012). An example of this would be the institutional investors in South Korea who have informal channels of communication with key insiders, such as controlling shareholders (Kim \& Cheong, 2015). Consequently, the risk perception of PRIIs is modified and in emerging economies, this would be lower for family-owned firms than non-family owned firms.

Hypothesis 5: In an emerging economy, family ownership of a firm strengthens the positive effect of pressure-resistant institutional investors on the level of international investments of these firms.

Figure 1 presents the hypotheses and the overall model being tested in the study.

Insert Figure 1 about here

\section{Data and methods}

\subsection{Data}

The sample for this study consisted of publicly listed Indian companies. India's economy has been classified as emergent or developing (Jain, 2006), thus contrasting it from the economies of countries such as the United States that have been the focus area for several earlier studies. The major source of firm-level data was the Prowess database published by the Centre for Monitoring Indian Economy (CMIE). This is a database of the financial performance of Indian companies. Our original dataset consisted of all listed companies in the Prowess database for the period 2005 to 2014. In the early 2000s, SEBI Clause 49 came into existence, which went through several amendments and revisions over the following years. Clause 49, which is a part of the listing agreement to the Indian stock exchange, has been formulated as a standard for the 
corporate governance of all listed companies and was implemented in phases between 2000 and 2004. Hence, we chose 2005 as the starting year of our research since these major corporate governance changes (related predominantly to board composition) could be reflected in a firm from the next year onwards. We extracted the initial sample of all listed firms and removed firms with missing data that could not be retrieved through any other databases or sources. The initial sample consisted of 40879 firm years and 6165 unique firms from 2005-2014. We dropped 5617 firm years where the net worth was negative or zero since these are bankrupt firms that are not operational but remain as legal entities due to legal restrictions on firm dissolution in India. Since the intent of our study was to understand the behavior of Indian firms, we removed 1513 subsidiary firm years belonging to foreign business groups and promoters. In addition, 3024 firm year observations with missing board data were removed, followed by those firms that belonged to the finance, insurance, and real estate sectors, leaving 16266 firm year observations in our sample. There were missing values for institutional shareholding for some of the firms and so our final sample size consisted of 7591 firm year observations across 2364 unique firms. In addition, we performed winsorizing on our explanatory variables, a technique that involves limiting extreme values in the statistical data to reduce the effect of possible outliers (Kennedy, Lakonishok \& Shaw, 1992).

\subsection{Variables}

\subsubsection{Dependent variable}

We used the log of annual foreign investments to measure internationalization. Foreign investments are the most important criterion for the internationalization of firms (Hassel, Höpner, Kurdelbusch, Rehder \& Zugehör, 2003) and the decision of a firm to invest in crossborder production activities is the most visible and important aspect of internationalization 
(Dunning, 1998). Previous studies on the emerging economies have frequently used this measure of internationalization from the Prowess database (e.g. Gaur, Kumar \& Singh, 2014; Singh \& Delios, 2017; Singh \& Gaur, 2013).

\subsubsection{Explanatory variables}

The explanatory variables in this study are the ownership shareholdings by different categories of owner. We have two measures of family shareholding. The first measure is a binary variable that takes the value 1 if a family is the single largest shareholder in a firm (Bhaumik, Driffield \& Pal, 2010; Claessens et al., 2002). Following Claessens et al., (2002), we assign a value of 1 to the dummy if the family holds at least $10 \%$ of the shares. The other measure is the total percentage of shares held by the family. Institutional ownership is measured in terms of the proportion (\%) of equity held by each specific group of institutional investors. Shareholding by banks, insurance companies, and other lending institutions constitute the measure of PSII. Though we consider PRIIs to be a theoretically single category, we operationalize them separately as either domestic PRIIs (such as mutual funds) or foreign institutional investors. This is because, in the context of the emerging economies, foreign institutional investors are a distinct entity and may present certain preferences distinct from other categories of pressure-resistant investors.

\subsubsection{Control Variables}

Comparable to other studies on India, we employ a dummy variable to indicate whether the firm is business group affiliated or not (Gaur \& Delios, 2015; Singh \& Gaur, 2013). We also control for board size, measured as the total number of directors on the board (Singh \& Delios, 2017), and board independence measured as the number of independent directors on the board as

a percentage of the total (Singh \& Delios, 2017; Singh \& Gaur, 2013). Extant literature has 
identified other financial variables that affect the level of the internationalization of a firm. These include the exports of a firm ( $\log$ of exports), size of the firm (Log of total assets), profitability of the firm (Return on assets), gearing ratio (Debt to equity ratio), age of the firm and the industry to which the firm belongs ${ }^{5}$ (e.g. Autio, Sapienza \& Almeida, 2000; Gaur \& Kumar, 2009; Singh \& Gaur, 2013; Singh \& Jun, 1995; Tihanyi et al., 2003). We also control for these variables in our study.

\subsection{Analytic procedure}

To estimate the association between institutional investors and internationalization, we use Tobit panel regression estimation techniques. The dependent variable of this study (log of total foreign investments) is clustered around the value 0 , since not every firm undertakes foreign investments every year. To assure that our estimation is not biased, we chose an estimation technique that takes care of clustered, censored variables (e.g. Banga, 2007; Bhaumik, Driffield $\&$ Pal, 2010). The overall model for our analysis is:

$$
\begin{aligned}
& L F I_{i, t}=\beta_{0}+\beta_{1} * F A M I L Y_{i, t-1}+\beta_{2} * P S I I_{i, t-1}+\beta_{3} * F I_{i, t-1}+\beta_{4} * M F_{i, t-1}+\beta_{5} \\
& \text { * }\left(\text { PSII }_{i, t-1} * F A M I L Y_{i, t-1}\right)+\beta_{6} *\left(F I I_{i, t-1} * F A M I L Y_{i, t-1}\right)+\beta_{7} \\
& \text { * }\left(M F_{i, t-1} * F A M I L Y_{i, t-1}\right)+\beta_{8} * B G . A f f_{i}+\beta_{9} * B O A R D S I Z E_{i, t-1}+\beta_{10} \\
& \text { * BOARDIND } D_{i, t-1}+\beta_{11} * \operatorname{EXPORTS}_{i, t-1}+\beta_{12} * \operatorname{LSIZE}_{i, t-1}+\beta_{13} \\
& * R O E_{i, t-1}+\beta_{14} * D E_{i, t-1}+\beta_{15} * A G E_{i, t-1}+\beta_{16} * \operatorname{INDUSTRY}_{i}+\beta_{17} \\
& \text { *YEAR }+\epsilon_{i, t}
\end{aligned}
$$

LFI is the logarithm of annual foreign investments. PSII, FII and MF indicate the percentage shareholding by pressure-sensitive institutional investors (banks and financial institutions), foreign institutional investors, and domestic mutual funds, respectively.

\footnotetext{
${ }^{5}$ Our sample has firms representing 6 primary industries as per the National Industry Classification (NIC): Manufacturing, services, construction, mining, agriculture, transportation. Firms belonging to finance, insurance, and real estate were dropped from the final sample since these firms are governed by a different set of corporate governance regulations (Faccio and Lasfer, 2000; Jaiswall \& Banerjee, 2012).
} 
Since our analysis includes important time invariant variables, such as family ownership, business group affiliation, and specific industry effects, random effects estimation is an appropriate analysis technique. However, our current model has various potential sources of endogeneity. Firstly, the internationalization of a firm is often influenced by firm-specific variables, and industry conditions and characteristics (Dastidar, 2009). Hence, the firm's decision to internationalize could be endogenous and self-selected (Campa \& Kedia, 2002; Gande, Schenzler, \& Senbet, 2009). To account for this within-firm variation in the data and to address some of the potential omitted variable bias, we also perform a fixed effects Tobit regression on our model. Since there is no sufficient statistic allowing the fixed effects to be conditioned out of likelihood, we employ an alternative semi-parametric estimation technique developed by Honoré (1992). The semi-parametric fixed effects estimation is performed on the family ownership represented as a percentage variable.

Secondly, current or past international investments of a firm could also influence the level of institutional investments in the firm (Zhou, Lan \& Tang, 2016), and this could lead to simultaneous endogeneity caused by past or contemporaneous correlation of both the dependent variable and the explanatory variables (Abdallah, Georgen \& O'Sullivan, 2015). Studies suggest that simultaneous endogeneity can be addressed by estimating a system of equations, i.e. twostage (2SLS) or three-stage (3SLS) least squares regression (Bascle, 2008; Shea, 1997). However, such a system requires external exogenous instruments, which in real practice are difficult to find, and/or very weak (Abdallah, Georgen \& O'Sullivan, 2015; Bound, Jaeger \& Baker, 1995). In the case of corporate governance-internationalization research in the emerging markets, the relative novelty of the field impairs us from identifying suitable instruments from 
the extant literature. Therefore, we have not been able to mitigate simultaneous endogeneity in our study, which is a shortcoming.

However, we lag the explanatory variables by one-year. This could mitigate to a limited extent the endogeneity between international investment and institutional investment inherent in corporate governance-international business research. Studies also highlight that a one-year lag best reflects a typical planning cycle (e.g. Geringer, Tallman, \& Olsen, 2000; Wan \& Hoskisson, 2003).

\section{Results}

The descriptive statistics and correlation matrix are provided in Table 2. We find that there is significant collinearity between certain variables. Firm size is especially strongly correlated to many other variables. Therefore, we ran regressions to test Variance Inflation Factors (VIF) for all the models. We found that all the variables had a VIF score of less than 5, eliminating any potential threat of significant multi-collinearity in our analyses.

Insert Table 2 about here

Tables 3 and 4 present the outcomes of the random effects and semi-parametric fixed effects Tobit panel regressions, respectively.

In both set of analyses, Model 1 is a control-variables-only model, whereas in Model 2 we have introduced our primary variable of interest, namely the family ownership variable, and shareholding by different categories of institutional investor. Models 3, 4 and 5 incorporate the different interactions, and Model 6 is the final model with all direct and interaction terms.

Insert Table 3 about here 
Insert Table 4 about here

In Tables 3 and 4, we discuss the direct association between ownership variables (family, PSII and PRII) on international investments based on Model 2. In the random effects regression analysis (Table 3), we find that family ownership is significantly and negatively associated with international investments $(\mathrm{p}<0.05)$. The result also holds in fixed effects regression analysis (Table 4, $\mathrm{p}<0.001)$. Therefore, we find support for Hypothesis 1. Both random and fixed effects regression analyses (Tables 3 and 4, Model 2) show that ownership by pressure-sensitive institutions has a negative association with international investments $(\mathrm{p}<0.05)$. This supports hypothesis 2 . Further, both kinds of pressure-resistant institutions (domestic as well as foreign) are positively associated with international investments. Tables 3 and 4 (Model 2) show a strongly positive relationship between FII and international investments $(\mathrm{p}<0.001)$. The relationship also holds for mutual funds and international investments, in both the random effects $(p<0.001)$ and fixed effects $(p<0.05)$ regression models. We thus gain support for hypothesis 3 .

Among the interactions, we find support for Hypothesis 4 (Model 3, Tables 3 and 4), where family ownership moderates PSIIs to still lower levels of international investment $(\mathrm{p}<0.05)$. Among the PRIIs, we find that FIIs support the internationalization of firms with family ownership (Model 4, Tables 3 and 4) whereas in case of domestic pressure-resistant institutional investors, such as mutual funds, this interaction is insignificant in both fixed and random effects estimation (Model 5, Tables 3 and 4). Therefore, our Hypothesis 5 is only partially supported. 
In estimating the economic significance of our findings, we find that a 1 percent increase in pressure-sensitive institutional investments (PSII) will result in a 1 percent decrease in the expected value of foreign investment (Model 2, Table 3). Also, a 1 percent increase in foreign institutional investments (FII) and pressure-sensitive institutional investments (MF) will result in a 2 percent increase in the expected value of foreign investment (Model 2, Table 3). Since family ownership is a dummy in random effects estimation, it could be inferred that the percentage impact of family ownership on the expected value of foreign investment is 4 percent less than that of non-family-owned firms (Model 2, Table 3). From Table 4, which presents the fixed effects Tobit estimation using a continuous measure of family ownership, we can interpret that a 1 percent change in family ownership will result in a 1 percent decrease in the expected value of foreign investments (Model 2, Table 4).

In addition, for a 1 percent increase in shareholding by pressure-sensitive institutional investors, there is an additional 1 percent decrease in expected international investment by family-owned firms compared to non-family-owned firms (Model 3, Table 3). In the case of foreign institutional investors, our results show that for every 1 percent increase in shareholding by foreign institutional investors, there is a 0.8 percent additional increase in expected international investment by family-owned firms compared to non-family-owned firms (Model 4, Table 3).

\subsection{Robustness tests}

In order to ensure the robustness of our results, we have performed various tests. Firstly, we have performed Tobit regression analysis on different samples separately, viz., from 2005-2009 and from 2010-2014. The primary reason for this split sample analysis is to ensure consistency in 
our results $^{6}$. The results of our analyses are presented in Tables 5 and 6. Qualitatively, the results across the two time-periods are similar to the main results.

Insert Table 5 about here

Secondly, previous studies (Bhaumik, Driffield \& Pal, 2010) have explored the effect of ownership and internationalization in specific sectors such as automobiles and pharmaceuticals. Bhaumik et al (2010) considered these industries to be particularly suitable for studying the internationalization behaviour of emerging market firms because firms that belong to these industries acquire significant assets. Accordingly, we conducted a subsample analysis on firms in the automobile and pharmaceutical industries. Table 7 presents the results of this analysis and we find the results are qualitatively similar to our main results.

Insert Table 7 about here

\section{Discussion}

Recent studies highlight the importance of risk characteristics that emanate from the focal point of the decision makers as a determinant of their internationalization choices (e.g. Buckley et al., 2018). In the context of the developed economies, it has been found that the risk attitudes of different categories of shareholder can alter their perceptions of particular transactions (e.g. Thomsen \& Pedersen, 2000). Specifically, with regard to institutional investors, it was seen that

\footnotetext{
${ }^{6}$ We thank an anonymous reviewer for highlighting the need to conduct a split sample analysis to ensure robustness across different time periods within our main sample.
} 
different categories of institutional investor have varying influences on the strategic decisionmaking of firms (e.g., internationalization, anti-takeover amendments, etc.,) (Brickley, Lease \& Smith, 1988; Tihanyi et al., 2003). Studies conducted from a capabilities perspective, acknowledge the idiosyncratic characteristics of firm owners in emerging economies (e.g., business groups and family ownership) and their influence on strategic decision-making by firms. However, they do not go on to discuss possible differences in the risk characteristics of controlling shareholders versus heterogeneous groups of non-controlling shareholders, nor their association with the strategic decision-making of firms (e.g., internationalization). Our study combines insights from institutional theory and behavioral risk perspective to examine both the direct and interactive effects of controlling owners (namely, family) and non-controlling owners (namely, pressure-sensitive institutional investors and pressure-resistant institutional investors) on the internationalization of emerging economy firms. The behavioral risk perspective helps us to determine the overall risk propensities and specific risk perceptions of different categories of owner with regards to internationalization, while the institutional context informs us how these perceptions are shaped. Consistent with other studies (e.g. Bhaumik, Driffield \& Pal, 2010; Ray, Mondal \& Ramachandran, 2018), our findings show that family ownership is negatively associated with internationalization. We also find that, while pressure-sensitive institutional investors are negatively associated with the internationalization of emerging economy firms, pressure-resistant investors have a positive association. Additionally, we find family ownership has a moderating effect on both pressure-sensitive institutional investors and pressure-resistant foreign institutional investors and internationalization. We contextualize and elaborate on our results in the light of previous studies. 
Family control has often been identified as an optimal ownership arrangement within the institutional environment of the emerging economies. However, we find that family ownership has a negative impact on firms' foreign investments. We argue that this negative impact arises due to the low risk propensity of the family, which results from their organizational inertia and attempts to preserve family traditions, and a reluctance to explore ideas beyond the existing resource selection patterns. This is further augmented by the high-risk perception of internationalization decisions that originates from the family-owned firm's unfamiliarity with the international environment. Moreover, we argue that the advantages of family ownership arise from the local institutional context of the emerging economies, and may not be easily transferred to international destinations (Gallo and Sveen, 1991; Gaur \& Kumar, 2009). Thus. such firms' unfamiliarity with the problem domain only increases. Our results are consistent with Bhaumik, Driffield \& Pal (2010) and Ray, Mondal \& Ramachandran (2018), who also find a negative association between family ownership and the outward FDI of Indian firms. We validate their findings and extend their arguments by showing that the risk-averse propensity of family owners, together with their instinct to preserve their socio-emotional wealth, are shaped by their risk perceptions in the institutional context in which they are embedded. At the same time, we find that our result differs from that of other studies, such as Singh \& Gaur (2013), who find a positive relationship between family ownership and internationalization. We suspect this may have arisen because their study period was from 2002 to 2009; prior to 2006, the level of corporate governance disclosure in Indian firms was relatively poor (Abraham, Marston \& Jones, 2015), which could have affected the availability of reported data.

Secondly, we find that in the emerging economy context, PSIIs act as monitors of their firms and have a negative impact on internationalization. This finding is in contrast to several 
studies in the developed economy context that identify PSIIs as passive monitors who consistently support the actions of management (e.g. Ferreira \& Matos, 2008; Muniandy, Tanewski \& Johl, 2016). In comparison to the developed economies, the institutional context of emerging economies is predominantly bank-centric, giving such lending institutions a dominant role in the strategic decisions of emerging economy firms. At the same time, under-developed alternative institutions (such as a strong capital market) makes such PSIIs the primary source of capital for emerging market firms, giving these institutions the dual role of shareholder and creditor (Dwivedi \& Jain, 2005). Therefore, in an emerging economy like India, PSIIs fulfill their dual role by actively participating in the corporate governance of an invested firm. Their active participation happens through the appointment of nominee directors (in lieu of a creditor agreement) to leverage the creditor relationship and influence the firm. Due to this dual relationship, PSIIs face a conflict of interest in that the role as equity shareholder requires them to support high-risk opportunities such as internationalization, while their creditor status impels them to oppose risky strategizing; our findings indicate that the creditor role generally prevails. Further, our results find support for the argument that the multiplexity of relationships between PSIIs and their investee firms generates high levels of PSII commitment and makes exiting the investee firm costly for them (Aguilera et al., 2003). Consequently, PSIIs dissuade investee firms from undertaking high-risk activities like internationalization.

Thirdly, we find that PRIIs, in the form of mutual funds, pension funds, and foreign institutional investors, positively impact internationalization. In India this category of investors has been roundly criticized for being uninterested in monitoring the firms in which they invest (Sarkar \& Sarkar, 2000) but we find that, in recent years, they have evolved to become strong and effective monitors of their investee firms. Recent reports increasingly suggest that there is a 
remarkable drop in the abstained voting percentages of domestic mutual funds in Indian companies, and that representatives of the funds now actively attend and vote during the annual meetings of companies, and make recommendations on how firms utilize their returns (Mukherjee, 2017). In the case of FIIs, it is argued that in the emerging economies they are risktaking specialists due to their extensive experience and understanding of the risk-return relationships across a variety of markets (Chittoor, Aulakh \& Ray, 2015). Our results extend this understanding by showing that the perception of risk for PRIIs (both foreign and domestic institutions) is lower owing to their better understanding of risk-return relationships, leading to their positive association with internationalization.

A major criticism of the current research in corporate governance is that the interactive behavior of the different entities of corporate governance, which could shape firm strategies, is often overlooked (Brunninge, Nordqvist \& Wiklund, 2007). Extant literature warrants an examination of the interplay between the institutional environment and firm governance (Aguilera et al., 2015). In this study, therefore, we examine the interactive behavior between controlling and non-controlling shareholders, and the overall effect of that interaction on the internationalization strategy of firms. We find that family ownership also moderates the relationship between PSII and internationalization. We find that family ownership increases still further the already high-risk-perception of PSIIs regarding internationalization. Thus familyowned firms become yet more conservative. Figure 2 graphically represents this interaction. The higher the level of family ownership, the more negative will be PSIIs' association with internationalization when compared with lower levels of family ownership levels.

Insert Figure 2 about here 
Although we hypothesized that PRIIs might be attracted to the option of internationalizing through family-owned firms due to the perceived lower levels of risk, we do not find complete support for this argument. We find that FIIs have a strong preference for family-owned firms, off-setting the institutional risks inherent in the emerging economies by opting for internationalization with a lower perceived risk. Because family ownership can protect firm investors against local institutional risks and the problems arising from a weaker institutional environment (Khanna \& Palepu, 2000), FIIs choose to support internationalization in family owned firms rather than in their non-family owned counterparts. Figure 3 represents this interaction relationship graphically.

Insert Figure 3 about here

On the other hand, we find that the risk-taking behavior of domestic PRIIs (e.g., mutual funds) is not affected by the family ownership of a firm. This implies that, despite their inherent higher risk propensity, domestic PRIIs see no distinction between a family-owned firm and a non-family-owned firm when it comes to deciding on their internationalization options. Unlike FIIs, these domestic money managers are familiar with the problem domain (i.e., the emerging economy) and hence, family ownership may not improve their risk perception of firm internationalization.

\section{Implications and Limitations}

\subsection{Implications for theory}

We contribute to the extant literature in three ways. Firstly, our study extends the understanding of ownership preferences in the not-so-well developed institutional environment of the emerging economies. While the extant literature argues that institutional context shapes 
ownership patterns and impacts the influence of ownership groups on internationalization decisions (Bhaumik, Driffield \& Pal, 2010), recent studies from the emerging economies add the dimension of the behavioral risk preferences of agents (or managers) when considering the internationalization of emerging economy firms (e.g. Buckley et al., 2018). Our study extends this further by highlighting how the institutional context, by shaping the individual risk perceptions of different categories of owner, affects the internationalization decisions of emerging market firms. It thereby fulfills the call for research on national corporate governance factors and their impact on the strategy, structure, and cognition of the multinational enterprise (Bhaumik, Driffield, Mickiewicz \& Vaaler, 2016). In addition, and in line with other recent studies (Chittoor, Aulakh \& Ray, 2018; Buckley et al., 2016), our study responds to a call for adopting a micro foundational approach to identifying the risk perceptions of different categories of decision-maker in the internationalization of emerging economy firms.

Secondly, we extend the behavioral risk theory by drawing insights obtained from the institutional lens. From a behavioral risk perspective, we argue that there is a negative association between family ownership and internationalization, and that this is derived from the risk propensity of family owners. We posit that the institutional environment of the emerging economies shapes the perception of risk for family owners, and their lack of familiarity with the problem domain exacerbates this perception of risk. Our study informs behavioral risk theory by highlighting how the institutional context shapes the risk preferences and strategic choices for the different categories of institutional investor. Therefore, by combining the institutional context and behavioral risk theory to explain the differences in the behavior of controlling and noncontrolling principals, we extend the theoretical insights on behavioral risk as derived from studies conducted on the developed economies to emerging economies. 
Thirdly, while extant literature highlights the principal-principal conflict among various shareholders in emerging economy firms (Dharwadkar et al., 2000; Morck et al., 2005; Young et al., 2008), our study argues that different categories of institutional investor can also serve as a disciplining mechanism on the controlling principals (i.e. family, affiliated CEO, and other managers). While the presence of powerful families who control many public companies through business groups create potential sources of conflict of interest for institutional investors (Hamdani \& Yafeh, 2012), the investors can act as effective monitors through formal mechanisms, such as 'majority-of-minority vote' (Goshen, 2003), or through informal dialogues and negotiations (Kim \& Cheong, 2015; Sarkar, 2010). Alternatively, some literature has identified that risk-averse family firms who lack internal expertise may build internationalization capabilities by attracting foreign holdings (Bhaumik, Driffield \& Pal, 2010). In this context, our study answers the call for an examination of the interplay between the various forms of ownership, monitoring and governance of these firms, and the institutional environment in which those firms are situated (Aguilera, Descender, Bender \& Lee, 2015; Singh \& Delios, 2017).

\subsection{Implications for practice}

Our study has implications for both family owners and institutional investors. First, we show that the owners and managers of a firm cannot ignore the heterogeneous nature of institutional investors. Owners and managers of firms in an emerging economy context who target risky strategies, such as internationalization, will benefit from reducing the shareholdings of pressure-sensitive investors (or creditors). They may also have to take steps to improve their corporate governance (transparency) so as to attract pressure-resistant investors. This, in turn, would help them build a reputational advantage of being attractive to FIIs. In addition, if an emerging economy firm is internationalizing, it should provide a credible signal of this to 
investors, in the form of increased family ownership. This would signal better value creation, leading to support from pressure-resistant investors.

\subsection{Limitations}

Our study is not without limitations. Like earlier studies, we were limited by our data to using a single measure of internationalization - namely, level of foreign investments. Although there are several other measures, some of which are multi-dimensional and could more effectively capture the internationalization strategy, we were prevented from attempting to use them by data availability issues.

We acknowledge that the country hosting overseas investment is a determinant of the internationalization decision. These differences could be based on the type of economy (developed vs. developing), or the differences in corporate governance standards and practices (such as investor protection) between the home and host countries. Further, the timing of investments (whether internationalization is at the early or later stages) is not controlled for in this study. The possibility of cross-listing for some of these firms, whereby they could be driven to better governance by the more stringent requirements of the foreign stock exchanges, also could not be precluded. However, data-related constraints have prevented us from including these in our study.

Finally, although we control for business groups, we do not control for the extent of business group tunneling that affects the relationship between institutional ownership and internationalization. We accept this as a limitation of the current study and believe that future studies might explore the importance of the extent of tunneling on the relationship between institutional ownership and internationalization. 


\section{References}

Abdallah, W., Goergen, M. and O'Sullivan, N. (2015). Endogeneity: How failure to correct for it can cause wrong inferences and some remedies. British Journal of Management, 26(4), 791-804.

Abraham, S., Marston, C. and Jones, E., 2015. Disclosure by Indian companies following corporate governance reform. Journal of Applied Accounting Research, 16(1), 114-137.

Aguilera, R. V., \& Jackson, G. (2003). The cross-national diversity of corporate governance: Dimensions and determinants. Academy of management Review, 28(3), 447-465.

Aguilera, R.V., Desender, K., Bednar, M.K. and Lee, J.H. (2015). Connecting the dots: Bringing external corporate governance into the corporate governance puzzle. Academy of Management Annals, 9(1), 483-573.

Andriosopoulos, D. and Yang, S. (2015). The impact of institutional investors on mergers and acquisitions in the United Kingdom. Journal of Banking \& Finance, 50, 547-561.

Autio, E., Sapienza, H. J., \& Almeida, J. G. (2000). Effects of age at entry, knowledge intensity, and imitability on international growth. Academy of management journal, 43(5), 909-924.

Bahree, M. (2013, August 19). Top Indian companies burdened with debt. Retrieved April 25, 2017, from https://www.forbes.com/sites/meghabahree/2013/08/19/top-indiancompanies-burdened-with-debt/\#4f8b35725d95

Banga, R. (2006). The export-diversifying impact of Japanese and US foreign direct investments in the Indian manufacturing sector. Journal of International Business Studies, 37(4), 558568.

Barney, J.B. and Hesterly, W. (2006). Organizational economics: Understanding the relationship between organizations and economic analysis. The SAGE handbook of organization studies, 110-148.

Bascle, G. (2008). Controlling for endogeneity with instrumental variables in strategic management research. Strategic organization, 6(3), 285-327

Baysinger, B. and Hoskisson, R.E. (1990). The composition of boards of directors and strategic control: Effects on corporate strategy. Academy of Management review, 15(1), 72-87.

Berman, K., \& Knight, J. (2014, July 23). When Is Debt Good? Retrieved April 25, 2017, from https://hbr.org/2009/07/when-is-debt-good

Berrone, P., Cruz, C., Gomez-Mejia, L.R. and Larraza-Kintana, M. (2010). Socioemotional wealth and corporate responses to institutional pressures: Do family-controlled firms pollute less?. Administrative Science Quarterly, 55(1), 82-113. 
Bhaumik, S., Driffield, N., Mickiewicz, T., \& Vaaler, P. (2017). National Corporate Governance and The Multinational Enterprise: Integrative and Disintegrative Trends In MNE Strategy, Structure and Cognition. Journal of World Business: Call for Papers.

Bhaumik, S. K., Driffield, N., \& Pal, S. (2010). Does ownership structure of emerging-market firms affect their outward FDI? The case of the Indian automotive and pharmaceutical sectors. Journal of International Business Studies, 41(3), 437-450.

Bodnaruk, A., Massa, M., \& Zeume, S. (2012, March 14). Country Governance and Foreign Investment in Business Groups. Retrieved April 25, 2017, from https://papers.ssrn.com/sol3/papers.cfm?abstract_id=2021049

Bound, J., Jaeger, D.A. and Baker, R.M. (1995). Problems with instrumental variables estimation when the correlation between the instruments and the endogenous explanatory variable is weak. Journal of the American statistical association, 90(430), 443-450.

Brickley, J. A., Lease, R. C., \& Smith, C. W. (1988). Ownership structure and voting on antitakeover amendments. Journal of financial economics, 20, 267-291.

Brunninge, O., Nordqvist, M., \& Wiklund, J. (2007). Corporate governance and strategic change in SMEs: The effects of ownership, board composition and top management teams. Small Business Economics, 29(3), 295-308.

Buckley, P.J., Chen, L., Clegg, L.J. and Voss, H. (2016). Experience and FDI risk-taking: A microfoundational reconceptualization. Journal of International Management, 22(2), $\underline{131-146 .}$

Buckley, P.J., Chen, L., Clegg, L.J. and Voss, H. (2018). Risk propensity in the foreign direct investment location decision of emerging multinationals. Journal of International Business Studies, 49(2), 153-171.

Burkart, M., Gromb, D., \& Panunzi, F. (1997). Large shareholders, monitoring, and the value of the firm. The quarterly journal of economics, 112(3), 693-728.

Campa, J.M. and Kedia, S. (2002). Explaining the diversification discount. The journal of finance, 57(4), 1731-1762.

Carpenter, M. A., Pollock, T. G., \& Leary, M. M. (2003). Testing a model of reasoned risktaking: governance, the experience of principals and agents, and global strategy in hightechnology IPO firms. Strategic Management Journal, 24(9), 803-820.

Chang, S. J., \& Choi, U. (1988). Strategy, structure and performance of Korean business groups: A transactions cost approach. The journal of industrial economics, 141-158.

Chittoor, R., Aulakh, P. S., \& Ray, S. (2015). What drives overseas acquisitions by Indian firms? A behavioral risk-taking perspective. Management International Review, 55(2), 255-275. 
Cho, J., \& Lee, J. (2017). The Impact of Ownership Structure on Internationalization: An Empirical Study of Korean SMEs. Global Business \& Finance Review, 22(1), 51-66.

Choe, H., Kho, B.C. and Stulz, R.M. (2001). Do domestic investors have more valuable information about individual stocks than foreign investors? (No. w8073). National bureau of economic research.

Chrisman, J.J., Chua, J.H. and Sharma, P. (2005). Trends and directions in the development of a strategic management theory of the family firm. Entrepreneurship theory and practice, 29(5), 555-576.

Ćirić, J., \& Njegomir, V. (2011). The supportive role of investment funds and insurance companies to entrepreneurship and innovations. In International Conference for Entrepreneurship, Innovation and Regional Development (ICEIRD, Skopje, FYRM).

Claessens, S., Djankov, S., Fan, J.P. and Lang, L.H. (2002). Disentangling the incentive and entrenchment effects of large shareholdings. The journal of finance, 57(6), 2741-2771.

Clarke, J.E. and Liesch, P.W. (2017). Wait-and-see strategy: Risk management in the internationalization process model. Journal of International Business Studies, 48(8), 923 940.

Coffee Jr, J.C. (1988). The Uncertain Case for Takeover Reform: An Essay on Stockholders, Stakeholders and Bust-Ups. Wisconsin Law Review., p.435.

Cui, L., \& Jiang, F. (2012). State ownership effect on firms' FDI ownership decisions under institutional pressure: a study of Chinese outward-investing firms. Journal of International Business Studies, 43(3), 264-284.

Dastidar, P. (2009). International corporate diversification and performance: Does firm selfselection matter?. Journal of International Business Studies, 40(1), 71-85.

David, P., Kochhar, R., \& Levitas, E. (1998). The effect of institutional investors on the level and mix of CEO compensation. Academy of Management Journal, 41(2), 200-208.

Del Guercio, D., \& Hawkins, J. (1999). The motivation and impact of pension fund activism. Journal of financial economics, 52(3), 293-340.

Del Guercio, D., \& Tkac, P. A. (1999, June 03). The Determinants of the Flow of Funds of Managed Portfolios: Mutual Funds versus Pension Funds. FRB Atlanta Working Paper 2000-21. Retrieved April 25, 2017, from https://papers.ssrn.com/sol3/papers.cfm?abstract_id=166431

Demirbag, M., McGuinness, M. and Altay, H. (2010). Perceptions of institutional environment and entry mode. Management International Review, 50(2), 207-240. 
Dharwadkar, B., George, G., \& Brandes, P. (2000). Privatization in emerging economies: An agency theory perspective. Academy of management review, 25(3), 650-669.

Dunning, J. H. (1998). Location and the multinational enterprise: a neglected factor? Journal of international business studies, 29(1), 45-66.

Dutton, J. E., \& Jackson, S. E. (1987). Categorizing strategic issues: Links to organizational action. Academy of management review, 12(1), 76-90.

Dvořák, T. (2005). Do domestic investors have an information advantage? Evidence from Indonesia. The Journal of Finance, 60(2), 817-839.

Dwivedi, N., \& Jain, A. K. (2005). Corporate governance and performance of Indian firms: The effect of board size and ownership. Employee Responsibilities and Rights Journal, 17(3), 161-172.

Dyer, W.G. (1986). Cultural change in family firms. Jossey-Bass, San Francisco.

Economic Times. (2016, August 02). Top 10 corporate groups owe Rs 5.73 lakh crore to lenders. Retrieved April 25, 2017, from http://economictimes.indiatimes.com/news/economy/finance/top-10-corporate-groupsowe-rs-5-73-lakh-crore-to-lenders/articleshow/53506840.cms

Faccio, M. and Lasfer, M.A. (2000). Do occupational pension funds monitor companies in which they hold large stakes?. Journal of Corporate Finance, 6(1), 71-110.

Ferreira, M. A., \& Matos, P. (2008). The colors of investors' money: The role of institutional investors around the world. Journal of Financial Economics, 88(3), 499-533.

Fiegenbaum, A., \& Thomas, H. (1988). Attitudes toward risk and the risk-return paradox: prospect theory explanations. Academy of Management journal, 31(1), 85-106.

Filatotchev, I., \& Mickiewicz, T. (2001). Ownership concentration, 'private benefits of control' and debt financing. Mickiewicz, T. (Ed). Corporate governance and finance in Poland and Russia (159-176). Palgrave Macmillan, New York.

Filatotchev, I. and Wright, M. (2011). Agency perspectives on corporate governance of multinational enterprises. Journal of Management Studies, 48(2), 471-486.

Firth, M., Lin, C., \& Wong, S. M. (2008). Leverage and investment under a state-owned bank lending environment: Evidence from China. Journal of Corporate Finance, 14(5), 642653.

Fogel, K. (2006). Oligarchic family control, social economic outcomes, and the quality of government. Journal of International Business Studies, 37(5), 603-622. 
Gallo, M. A., \& Sveen, J. (1991). Internationalizing the family business: Facilitating and restraining factors. Family Business Review, 4(2), 181-190.

Gande, A., Schenzler, C. and Senbet, L.W. (2009). Valuation effects of global diversification. Journal of International Business Studies, 40(9), 1515-1532.

Gaur, A., \& Delios, A. (2015). International diversification of emerging market firms: The role of ownership structure and group affiliation. Management International Review, 55(2), 235-253.

Gaur, A. S., \& Kumar, V. (2009). International diversification, business group affiliation and firm performance: Empirical evidence from India. British Journal of Management, 20(2), 172-186.

Gaur, A.S., Kumar, V. and Singh, D. (2014). Institutions, resources, and internationalization of emerging economy firms. Journal of World Business, 49(1), 12-20.

George, E., Chattopadhyay, P., Sitkin, S.B. and Barden, J. (2006). Cognitive underpinnings of institutional persistence and change: A framing perspective. Academy of Management Review, 31(2), 347-365.

George, G., Wiklund, J., \& Zahra, S. A. (2005). Ownership and the internationalization of small firms. Journal of Management, 31(2), 210-233.

Geringer, J. M., Tallman, S., \& Olsen, D. M. (2000). Product and international diversification among Japanese multinational firms. Strategic Management Journal, 51-80.

Giannetti, M., \& Ongena, S. (2005, August 17). Financial Integration and Entrepreneurial Activity: Evidence from Foreign Bank Entry in Emerging Markets. Retrieved April 25, 2017, from https://papers.ssrn.com/sol3/papers.cfm?abstract_id=785247

Gilbert, C.G. (2005). Unbundling the structure of inertia: Resource versus routine rigidity. Academy of management journal, 48(5), 741-763.

Gillan, S. L., \& Starks, L. T. (2003). Corporate Governance, Corporate Ownership, and the Role of Institutional Investors: A Global Perspective. Journal of Applied Finance, 13(2), 4.

Goldberg, L., Dages, B. G., \& Kinney, D. (2000). Foreign and domestic bank participation in emerging markets: Lessons from Mexico and Argentina (No. w7714). National bureau of economic research.

Gómez-Mejía, L. R., Haynes, K. T., Núñez-Nickel, M., Jacobson, K. J., \& Moyano-Fuentes, J. (2007). Socioemotional wealth and business risks in family-controlled firms: Evidence from Spanish olive oil mills. Administrative science quarterly, 52(1), 106-137. 
Goshen, Z. (2003). The efficiency of controlling corporate self-dealing: Theory meets reality. California Law Review, 91, 393-438.

Guillén, M.F. (2002). Structural inertia, imitation, and foreign expansion: South Korean firms and business groups in China, 1987-1995. Academy of Management Journal, 45(3), 509525.

Hamdani, A., \& Yafeh, Y. (2012). Institutional investors as minority shareholders. Review of Finance, 17, 1-35.

Hannan, M.T. and Freeman, J. (1977). The population ecology of organizations. American journal of sociology, 82(5), 929-964.

Hannan, M.T. and Freeman, J. (1984). Structural inertia and organizational change. American sociological review, 82, 149-164.

Hartzell, J. C., \& Starks, L. T. (2003). Institutional investors and executive compensation. The Journal of Finance, 58(6), 2351-2374.

Hassel, A., Höpner, M., Kurdelbusch, A., Rehder, B., \& Zugehör, R. (2003). Two dimensions of the internationalization of firms. Journal of Management Studies, 40(3), 705-723.

Honoré, B.E. (1992). Trimmed LAD and least squares estimation of truncated and censored regression models with fixed effects. Econometrica: journal of the Econometric Society, 60, 533-565.

Iacoviello, M. and Minetti, R. (2006). International business cycles with domestic and foreign lenders. Journal of Monetary Economics, 53(8), 2267-2282.

Jackson, S. E., \& Dutton, J. E. (1988). Discerning threats and opportunities. Administrative Science Quarterly, 33, 370-387.

Jain, S. C. (Ed.). (2006). Emerging economies and the transformation of international business: Brazil, Russia, India and China (BRICs). Edward Elgar Publishing, Cheltenham, UK.

Jaiswall, M. and Banerjee, A. (2012). Exploring the relationship between Earnings Management and Corporate Governance characteristics in the Indian context. IIM Calcutta WPS, (704).

Jensen, M. C., \& Meckling, W. H. (1976). Theory of the firm: Managerial behavior, agency costs and ownership structure. Journal of financial economics, 3(4), 305-360.

Kahneman, D., \& Tversky, A. (1979). Prospect theory: An analysis of decision under risk. Econometrica: Journal of the econometric society, 47, 263-291.

Kennedy, D., Lakonishok, J. and Shaw, W.H. (1992). Accommodating outliers and nonlinearity in decision models. Journal of Accounting, Auditing \& Finance, 7(2), 161-190. 
Khanna, T., and Palepu, K. (1997). Why focused strategies may be wrong for emerging markets. Harvard business review, 75 (4), 41-54.

Khanna, T., \& Palepu, K. (2000). The future of business groups in emerging markets: Long-run evidence from Chile. Academy of Management journal, 43(3), 268-285.

Khwaja, A. I., \& Mian, A. (2011). Rent seeking and corruption in financial markets. Annual. Revue of economics, 3(1), 579-600.

Kim, B. (2011). Do foreign investors encourage value-enhancing corporate risk taking? Emerging Markets Finance and Trade, 47(3), 88-110.

Kim, J.B. and Cheong, H.Y.(2015). Foreign versus domestic institutional investors in emerging markets: Who contributes more to firm-specific information flow? China journal of accounting research, 8(1), 1-23.

Klapper, L. F., \& Love, I. (2004). Corporate governance, investor protection, and performance in emerging markets. Journal of corporate Finance, 10(5), 703-728.

Kochhar, R., \& David, P. (1996). Institutional investors and firm innovation: A test of competing hypotheses. Strategic Management Journal, 17,73-84.

La Porta, R., Lopez-de-Silanes, F., Shleifer, A., \& Vishny, R. (1999). The quality of government. Journal of Law, Economics, and organization, 15(1), 222-279.

Lambert, R.D. (1986). Points of leverage: An agenda for a national foundation for international studies. Social Science Research Council, New York.

Lee, J. (2015). Hybrid Corporate Governance: The Case of Asia. Review of Contemporary Business Research, 3(3), 21-36.

Lensink, R., Van der Molen, R., \& Gangopadhyay, S. (2003). Business groups, financing constraints and investment: The case of India. The Journal of Development Studies, 40(2), 93-119.

Libby, R., \& Fishburn, P. C. (1977). Behavioral models of risk taking in business decisions: A survey and evaluation. Journal of Accounting Research, 15, 272-292.

Lien, Y. C., Piesse, J., Strange, R., \& Filatotchev, I. (2005). The role of corporate governance in FDI decisions: Evidence from Taiwan. International Business Review, 14(6), 739-763.

Majocchi, A., Odorici, V., \& Presutti, M. (2013). Corporate ownership and internationalization: The effects of family, bank and institutional investor ownership in the UK and in continental Europe. Corporate Ownership and Control, 10(2), 721-732. 
Makhija, M.V. and Stewart, A.C. (2002). The effect of national context on perceptions of risk: A comparison of planned versus free-market managers. Journal of International Business Studies, 33(4), 737-756.

March, J.G. (1978). Bounded rationality, ambiguity, and the engineering of choice. The Bell Journal of Economics, 9, 587-608.

March, J.G. (1997). Understanding how decisions happen in organizations. Organizational decision making, 10, 9-32.

March, J.G. and Shapira, Z. (1987). Managerial perspectives on risk and risk taking. Management science, 33(11), 1404-1418.

Miller, S., D. Hickson \& D. Wilson. (1996). Decision Making in Organizations. In S. Clegg, C. Hardy and W. Nord (Eds.), Handbook of Organization Studies. London, Great Britain: Sage Publications.

Mintzberg, H., Raisinghani, D. and Theoret, A., (1976). The structure of" unstructured" decision processes. Administrative science quarterly, 21, 246-275.

Morck, R., Wolfenzon, D. and Yeung, B. (2005). Corporate governance, economic entrenchment, and growth. Journal of economic literature, 43(3), 655-720.

Morck, R., Yeung, B. and Zhao, M. (2008). Perspectives on China's outward foreign direct investment. Journal of International Business Studies, 39(3), 337-350.

Mukherjee, R. (2017) Minority investors rush to be part of cos'mgmt', The Times of India, 22 September. Available at https://timesofindia.indiatimes.com/business/indiabusiness/minority-investors-rush-to-bepart-of-cos-mgmt/articleshow/60787117.cms (Accessed 14 October 2017).

Muniandy, P., Tanewski, G., \& Johl, S. K. (2016). Institutional investors in Australia: Do they play a homogenous monitoring role?. Pacific-Basin Finance Journal, 40, 266-288.

Nachane, D. M., Ghosh, S., \& Ray, P. (2005). Bank nominee directors and corporate performance: micro-evidence for India. Economic and Political Weekly, 19, 1216-1223.

Naldi, L., Nordqvist, M., Sjöberg, K. and Wiklund, J. (2007). Entrepreneurial orientation, risk taking, and performance in family firms. Family business review, 20(1), 33-47.

North, D.C. (1990). A transaction cost theory of politics. Journal of theoretical politics, 2(4), 355-367.

Pablo, A. L., Sitkin, S. B., \& Jemison, D. B. (1996). Acquisition decision-making processes: The central role of risk. Journal of Management, 22(5), 723-746. 
Pan, X., \& Tian, G. G. (2015). Does banks' dual holding affect bank lending and firms' investment decisions? Evidence from China. Journal of Banking \& Finance, 55, 406-424.

Park, S. (2000). Effects of the affiliation of banking and commerce on the firm's investment and the bank's risk. Journal of banking \& Finance, 24(10), 1629-1650.

Peng, M. W. (2003). Institutional transitions and strategic choices. Academy of management review, 28(2), 275-296.

Pepper, A. and Gore, J. (2014). The economic psychology of incentives: An international study of top managers. Journal of World Business, 49(3), 350-361.

Priem, R.L. (1990). Top management team group factors, consensus, and firm performance. Strategic Management Journal, 11(6), 469-478.

Ramaswamy, K., Li, M., \& Veliyath, R. (2002). Variations in ownership behavior and propensity to diversify: A study of the Indian corporate context. Strategic Management Journal, 23(4), 345-358.

Ray, S., Mondal, A. and Ramachandran, K. (2018). How does family involvement affect a firm's internationalization? An investigation of Indian family firms. Global Strategy Journal, 8(1), 73-105.

Rubach, M.J. and Sebora, T.C. (1998). Comparative corporate governance: Competitive implications of an emerging convergence. Journal of World Business, 33(2), 167-184.

Samal, K. C. (1997). Emerging equity market in India: role of foreign institutional investors. Economic and Political Weekly, 32(42), 2729-2732.

Sarkar, J., \& Sarkar, S. (2000). Large shareholder activism in corporate governance in developing countries: Evidence from India. International Review of Finance, 1(3), 161194.

Sarkar, J. (2010). Ownership and corporate governance in Indian firms. Corporate governance: An emerging scenario, National Stock Exchange of India Ltd, 217-267.

Sarkar, J., Sarkar, S. and Sen, K. (2008). Board of directors and opportunistic earnings management: Evidence from India. Journal of Accounting, Auditing \& Finance, 23(4), $517-551$.

Schreyögg, G. and Kliesch-Eberl, M. (2007). How dynamic can organizational capabilities be? Towards a dual-process model of capability dynamization. Strategic management journal, 28(9), 913-933.

Schulze, W.S., Lubatkin, M.H. and Dino, R.N. (2002). Altruism, agency, and the competitiveness of family firms. Managerial and decision economics, 23(4-5), 247-259. 
Schwenk, C.R. (1988). The cognitive perspective on strategic decision making. Journal of management studies, 25(1), 41-55.

Seasholes, M. (2000). Smart foreign traders in emerging markets. unpublished Harvard Business School working paper, Boston, MA

Shapira, Z. (1997). Organizational Decision Making. Cambridge, MA: Cambridge University Press

Sharma, P., Chrisman, J.J. and Chua, J.H. (1997). Strategic management of the family business: Past research and future challenges. Family business review, 10(1), 1-35.

Shavell, S. (1979). Risk sharing and incentives in the principal and agent relationship. The Bell Journal of Economics, 10(1), 55-73.

Shea, J. (1997). Instrument relevance in multivariate linear models: A simple measure. Review of Economics and Statistics, 79(2), 348-352.

Shenkar, O. and Von Glinow, M.A. (1994). Paradoxes of organizational theory and research: Using the case of China to illustrate national contingency. Management Science, 40(1), 56-71.

Singh, D., \& Delios, A. (2017). Corporate governance, board networks and growth in domestic and international markets: Evidence from India. Journal of World Business, 52(5), 615627.

Singh, D. A., \& Gaur, A. S. (2013). Governance structure, innovation and internationalization: evidence from India. Journal of International Management, 19(3), 300-309.

Singh, H., \& Jun, K. W. (1995). Some new evidence on determinants of foreign direct investment in developing countries (No. 1531). World Bank Publications, Washington D. C.

Sitkin, S. B., \& Pablo, A. L. (1992). Reconceptualizing the determinants of risk behavior. Academy of management review, 17(1), 9-38.

Sitkin, S.B. and Weingart, L.R. (1995). Determinants of risky decision-making behavior: A test of the mediating role of risk perceptions and propensity. Academy of management Journal, 38(6), 1573-1592.

Thomsen, S., \& Pedersen, T. (2000). Ownership structure and economic performance in the largest European companies. Strategic Management Journal, 21, 689-705.

Tihanyi, L., Johnson, R. A., Hoskisson, R. E., \& Hitt, M. A. (2003). Institutional ownership 
differences and international diversification: The effects of boards of directors and technological opportunity. Academy of Management Journal, 46(2), 195-211.

Tirole, J. (2002). Financial crises, liquidity, and the international monetary system (Vol. 6). Princeton University Press, New Jersey.

Tversky, A. and Kahneman, D. (1981). The framing of decisions and the psychology of choice. Science, 211(4481), 453-458.

Varma, J. R. (1997). Corporate governance in India: Disciplining the dominant shareholder. IIMB Management Review, 9(4), 5-18.

Villalonga, B. and Amit, R. (2006). How do family ownership, control and management affect firm value? Journal of financial Economics, 80(2), 385-417.

Vlek, C., \& Stallen, P. J. (1980). Rational and personal aspects of risk. Acta psychologica, 45(1), 273-300.

Wan, W. P., \& Hoskisson, R. E. (2003). Home country environments, corporate diversification strategies, and firm performance. Academy of Management journal, 46(1), 27-45.

Ward, J.L. (1997). Growing the family business: Special challenges and best practices. Family Business Review, 10(4), 323-337.

Wąsowska, A. (2013). Ownership Structure and the Internationalization Process of Publiclylisted Companies in Poland. Management and Business Administration. Central Europe, 3 (122), 82-97.

Welch, I. (1997). Why is bank debt senior? A theory of asymmetry and claim priority based on influence costs. Review of Financial Studies, 10(4), 1203-1236.

Wiseman, R.M. and Catanach Jr, C. (1997). A longitudinal disaggregation of operational risk under changing regulations: Evidence from the savings and loan industry. Academy of Management Journal, 40(4), 799-830.

Wiseman, R.M. and Gomez-Mejia, L.R. (1998). A behavioral agency model of managerial risk taking. Academy of management Review, 23(1), 133-153.

World Bank. (2005, June). India: Role of Institutional Investors in the Corporate Governance of their Portfolio Companies. Retrieved April 25, 2017, from http://www.nfcgindia.org/final_india-june29.pdf

Young, M. N., Peng, M. W., Ahlstrom, D., Bruton, G. D., \& Jiang, Y. (2008). Corporate governance in emerging economies: A review of the principal-principal perspective. Journal of management studies, 45(1), 196-220. 
Zhang, J., \& Ma, H. (2009). Adoption of professional management in Chinese family business: A multilevel analysis of impetuses and impediments. Asia Pacific Journal of Management, 26(1), 119-139.

Zhou, J., Lan, W. and Tang, Y., 2016. The value of institutional shareholders: Evidence from cross-border acquisitions by Chinese listed firms. Management Decision, 54(1), pp.4465 . 


\section{Figure 1: Model presenting hypotheses}

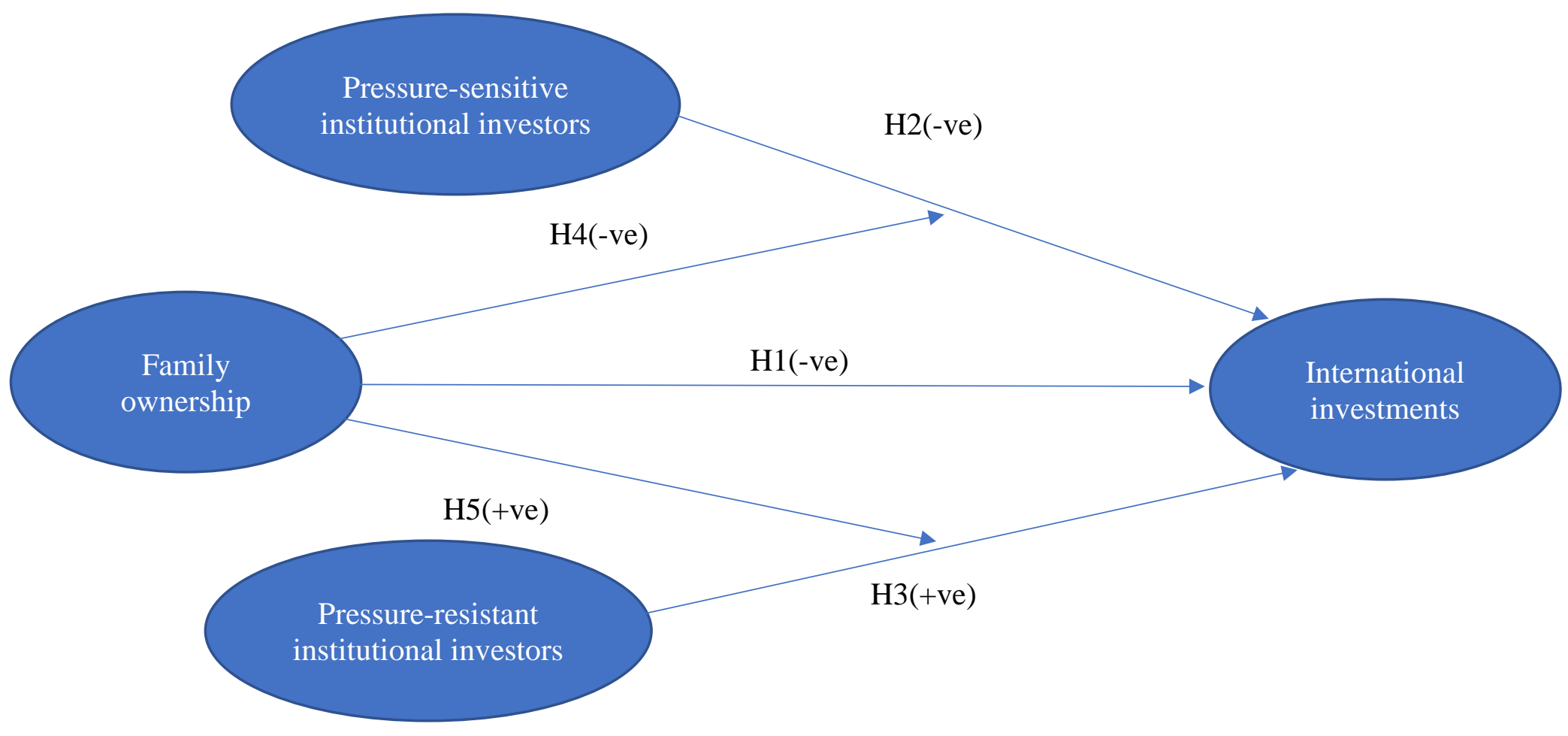


Figure 2: PSII and international investments: The moderating role of family ownership

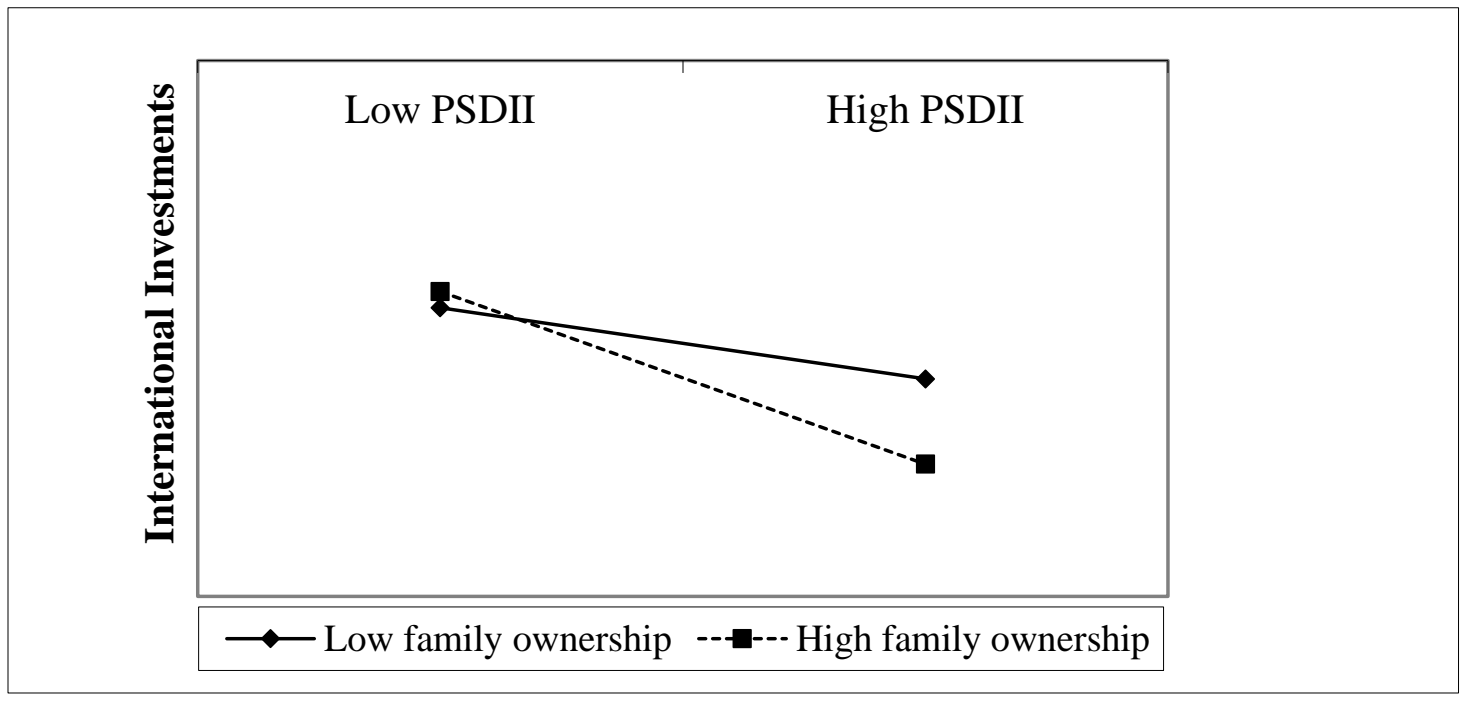


Figure 3: FII and international investments: The moderating role of family ownership

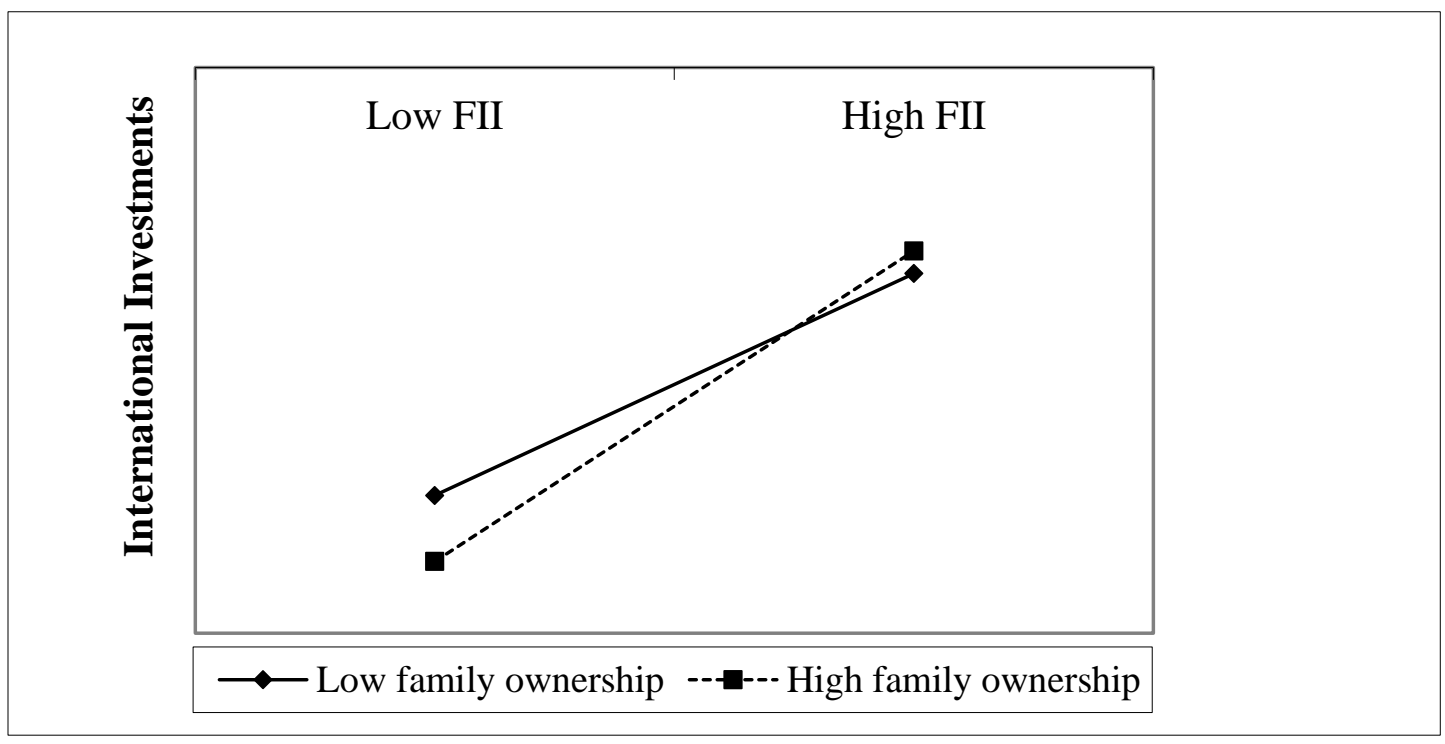


Table 1: Risk characteristics of institutional investors

\begin{tabular}{|l|l|l|l|l|}
\hline $\begin{array}{l}\text { Type of } \\
\text { owner }\end{array}$ & $\begin{array}{l}\text { Mechanism of } \\
\text { monitoring }\end{array}$ & Risk propensity & Risk perception & $\begin{array}{l}\text { Association with } \\
\text { internationalization }\end{array}$ \\
\hline Family & Controlling shareholders & Low or High & High & Negative \\
\hline PSII & $\begin{array}{l}\text { Dual control: creditor- } \\
\text { investor }\end{array}$ & How & High & Negative \\
\hline PRII & $\begin{array}{l}\text { Activism, external market } \\
\text { for control }\end{array}$ & High & Low & Positive \\
\hline
\end{tabular}


Table 2: Summary statistics and correlation matrix

\begin{tabular}{|c|c|c|c|c|c|c|c|c|c|c|c|c|c|}
\hline Variable & Mean & Std. & 1 & 2 & 3 & 4 & 5 & 6 & 7 & 8 & 9 & 10 & 11 \\
\hline Foreign Investment & 9.30 & 160.86 & & & & & & & & & & & \\
\hline 1.Family & 39.8 & 24.9 & 1.00 & & & & & & & & & & \\
\hline 2.PSII & 1.58 & 3.97 & $-.1^{*}$ & 1.00 & & & & & & & & & \\
\hline 3.PRII-FII & 2.89 & 6.86 & $-.06^{* *}$ & $0.15^{* *}$ & 1.00 & & & & & & & & \\
\hline 4.PRII-MF & 1.24 & 3.15 & -0.04 & $0.18 *$ & $0.36 * *$ & 1.00 & & & & & & & \\
\hline 5.Board Size & 9.90 & 3.59 & $0.03 * *$ & $0.23 * *$ & $0.34 *$ & $0.26^{* *}$ & 1.00 & & & & & & \\
\hline 6.Board Independence & 0.36 & 0.16 & $0.05^{* *}$ & 0.02 & $0.06^{*}$ & $0.04 * *$ & $0.12 *$ & 1.00 & & & & & \\
\hline 7.Exports & 14.62 & 55.40 & $.01^{* *}$ & 0.01 & $0.04 *$ & $0.03 *$ & $0.05 *$ & $0.02 *$ & 1.00 & & & & \\
\hline 8.Total Assets & 444.93 & 3226.24 & $-.1^{* *}$ & $0.21 * *$ & $0.20 *$ & $0.09 *$ & $0.27 *$ & $-0.04 *$ & -0.01 & 1.00 & & & \\
\hline 9.ROA & -153.84 & 15919.80 & 0.06 & 0.00 & 0.00 & 0.00 & -0.01 & $-0.02 *$ & 0.00 & 0.00 & 1.00 & & \\
\hline 10.Debt to Equity & 1.86 & 27.66 & $.06^{* *}$ & $0.01 *$ & -0.01 & -0.01 & 0.00 & 0.00 & 0.00 & 0.00 & 0.00 & 1.00 & \\
\hline 11.Age & 28.42 & 17.87 & $-0.01^{* *}$ & 0.01 & 0.00 & 0.00 & 0.00 & -0.01 & 0.00 & $-0.01 *$ & 0.00 & 0.00 & 1.00 \\
\hline
\end{tabular}

**. Correlation is significant at the 0.01 level (2-tailed).

*. Correlation is significant at the 0.05 level (2-tailed). 
Table 3: Results of random effect Tobit regression for types of institutional investors

\begin{tabular}{|c|c|c|c|c|c|c|c|c|c|c|c|c|}
\hline & \multicolumn{2}{|c|}{ Model 1} & \multicolumn{2}{|c|}{ Model 2} & \multicolumn{2}{|c|}{ Model 3} & \multicolumn{2}{|c|}{ Model 4} & \multicolumn{2}{|c|}{ Model 5} & \multicolumn{2}{|c|}{ Model 6} \\
\hline & $\beta$-value & S.d & $\beta$-value & S.d & $\beta$-value & S.d & $\beta$-value & S.d & $\beta$-value & S.d & $\beta$-value & S.d \\
\hline Intercept & $-5.2 * * *$ & 0.46 & $-4.9 * * *$ & 0.46 & $-4.9 * * *$ & 0.48 & $-4.9 * * *$ & 0.48 & $-4.9 * * *$ & 0.46 & $-4.8 * * *$ & 0.46 \\
\hline \multicolumn{13}{|l|}{ Variables } \\
\hline \multicolumn{13}{|l|}{ Explanatory Variables } \\
\hline FAMILY $^{\phi}$ & & & $-0.04 *$ & 0.07 & $-0.01 *$ & 0.08 & $-0.05^{*}$ & 0.08 & $-0.002 *$ & 0.08 & $-0.02 *$ & 0.08 \\
\hline PSII & & & $-0.01 *$ & 0.007 & $-0.007 *$ & 0.001 & $-0.01 *$ & 0.007 & $-0.01 *$ & 0.007 & $-0.008 *$ & 0.01 \\
\hline PRII-FII & & & $0.02 * * *$ & 0.003 & $0.02 * * *$ & 0.003 & $0.02 * * *$ & 0.003 & $0.018 * * *$ & 0.015 & $0.02 * * *$ & 0.005 \\
\hline PRII-MF & & & $0.02 * * *$ & 0.006 & $0.02 * * *$ & 0.006 & $0.01 *$ & 0.01 & $0.02 * * *$ & 0.06 & $0.013^{*}$ & 0.01 \\
\hline \multicolumn{13}{|l|}{ Interactions } \\
\hline PSII*FAMILY & & & & & $-0.01 *$ & 0.01 & & & & & $-0.09 *$ & 0.01 \\
\hline PRII-FII*FAMILY & & & & & & & $0.008^{*}$ & 0.004 & & & $0.006^{*}$ & 0.005 \\
\hline PRII-MF*FAMILY & & & & & & & & & 0.016 & 0.01 & 0.012 & 0.01 \\
\hline \multicolumn{13}{|l|}{ Control Variables } \\
\hline BG_Aff & $0.37 * * *$ & 0.1 & $0.24 * * *$ & 0.1 & $0.2 * * *$ & 0.1 & $0.23 * * *$ & 0.1 & $0.24 * * *$ & 0.1 & $0.23^{* * *}$ & 0.1 \\
\hline Board Size & $0.06 * * *$ & 0.007 & $0.06 * * *$ & 0.008 & $0.06 * * *$ & 0.008 & $0.06 * * *$ & 0.008 & $0.06 * * *$ & 0.008 & $0.06 * * *$ & 0.008 \\
\hline Board Independence & $0.25^{*}$ & 0.13 & 0.19 & 0.13 & 0.19 & 0.13 & 0.19 & 0.13 & 0.19 & 0.13 & 0.19 & 0.13 \\
\hline Exports & $0.01 * * *$ & 0.001 & $0.01 * * *$ & 0.001 & $0.01 * * *$ & 0.001 & $0.01 * * *$ & 0.001 & $0.01 * * *$ & 0.001 & $0.01 * * *$ & 0.001 \\
\hline Lsize & $0.87 * * *$ & 0.03 & $0.8 * * *$ & 0.03 & $0.87 * * *$ & 0.03 & $0.8 * * *$ & 0.03 & $0.87 * * *$ & 0.03 & $0.8 * * *$ & 0.03 \\
\hline ROA & 0.01 & 0.02 & 0.01 & 0.02 & 0.01 & 0.02 & 0.01 & 0.02 & 0.01 & 0.02 & 0.01 & 0.02 \\
\hline $\mathrm{DE}$ & $-0.05 * *$ & 0.02 & -0.005 & 0.01 & -0.002 & 0.01 & -0.005 & 0.01 & -0.004 & 0.01 & -0.002 & 0.01 \\
\hline Age & $-0.001 *$ & 0.001 & $-0.001 *$ & 0.001 & $-0.001 *$ & 0.001 & \begin{tabular}{|l|}
$-0.001 *$ \\
\end{tabular} & 0.001 & $-0.001 *$ & 0.001 & $-0.001 *$ & 0.001 \\
\hline \multicolumn{13}{|l|}{ Model fit } \\
\hline $\mathrm{N}$ & 16266 & 7591 & 7591 & 7591 & 7591 & 7591 & & & & & & \\
\hline Wald-Chi ${ }^{2}$ & \multicolumn{2}{|l|}{$902.9 * * *$} & \multicolumn{2}{|l|}{$983.8 * * *$} & \multicolumn{2}{|c|}{$985.22 * * *$} & \multicolumn{2}{|c|}{$985.07 * * *$} & \multicolumn{2}{|l|}{$987.04 * * *$} & \multicolumn{2}{|l|}{$988.5 * * *$} \\
\hline
\end{tabular}

All explanatory variables have been lagged by one year. Industry and year have been controlled for, but not reported.

McFadden $\mathrm{R}^{2}$ is 0.42 for models 2 to $6 . * * * \mathrm{p}<0.001 * * \mathrm{p}<0.01 * \mathrm{p}<0.05{ }^{\wedge} \mathrm{p}<0$.

The reported standard errors are computed through bootstrapping technique.

$\phi$ Family shareholding is measured as a dummy variable 
Table 4: Results of Semi Parametric Fixed Effects Tobit Regression

\begin{tabular}{|c|c|c|c|c|c|c|c|c|c|c|c|c|}
\hline & \multicolumn{2}{|c|}{ Model 1} & \multicolumn{2}{|c|}{ Model 2} & \multicolumn{2}{|c|}{ Model 3} & \multicolumn{2}{|c|}{ Model 4} & \multicolumn{2}{|c|}{ Model 5} & \multicolumn{2}{|c|}{ Model 6} \\
\hline & $\beta$-value & S.d & $\beta$-value & S.d & $\beta$-value & S.d & $\beta$-value & S.d & $\beta$-value & S.d & $\beta$-value & S.d \\
\hline \multicolumn{13}{|l|}{$\begin{array}{l}\text { Explanatory } \\
\text { Variables }\end{array}$} \\
\hline FAMILY $^{\phi}$ & & & $-0.01 * * *$ & 0.001 & $-0.008 * * *$ & 0.001 & $-0.005 * * *$ & 0.001 & $-0.008 * * *$ & 0.001 & $-0.004 * *$ & 0.002 \\
\hline PSII & & & $-0.004 *$ & 0.012 & $-0.019 *$ & 0.015 & $-0.006^{*}$ & 0.012 & $-0.005^{*}$ & 0.012 & $-0.018^{*}$ & 0.014 \\
\hline PRII-FII & & & $0.01 * * *$ & 0.005 & $0.01 * * *$ & 0.005 & $0.01 * *$ & 0.007 & $0.11 * * *$ & 0.005 & $0.01 * *$ & 0.007 \\
\hline PRII-MF & & & $0.012 *$ & 0.01 & $0.012 *$ & 0.01 & $0.01 *$ & 0.01 & $0.025^{*}$ & 0.012 & $0.01 *$ & 0.01 \\
\hline \multicolumn{13}{|l|}{ Interactions } \\
\hline PSII*FAMILY & & & & & $-0.007 *$ & 0.003 & & & & & $-0.005^{*}$ & 0.003 \\
\hline PRII-FII*FAMILY & & & & & & & $0.001 * * *$ & 0.001 & & & $0.006 * * *$ & 0.001 \\
\hline PRII-MF*FAMILY & & & & & & & & & 0.004 & 0.002 & 0.009 & 0.002 \\
\hline \multicolumn{13}{|l|}{ Control Variables } \\
\hline Board Size & $0.03 * * *$ & 0.01 & $0.03 * * *$ & 0.01 & $0.03 * * *$ & 0.01 & $0.03 * * *$ & 0.01 & $0.03 * * *$ & 0.01 & $0.03 * * *$ & 0.01 \\
\hline Board Independence & 0.27 & 0.02 & 0.25 & 0.02 & 0.02 & 0.27 & 0.02 & 0.26 & 0.03 & 0.27 & 0.02 & 0.27 \\
\hline Exports & $0.003 *$ & 0.001 & $0.003 *$ & 0.001 & $0.003 *$ & 0.001 & $0.003^{*}$ & 0.001 & $0.003 *$ & 0.001 & $0.003 *$ & 0.001 \\
\hline Lsize & $0.04 * * *$ & 0.002 & $0.04 * * *$ & 0.002 & $0.04 * * *$ & 0.002 & $0.04 * * *$ & 0.002 & $0.04 * * *$ & 0.002 & $0.04 * * *$ & 0.002 \\
\hline ROA & -0.001 & 0.002 & -0.001 & 0.002 & -0.001 & 0.002 & -0.001 & 0.002 & -0.001 & 0.002 & -0.001 & 0.002 \\
\hline $\mathrm{DE}$ & -0.001 & 0.004 & -0.001 & 0.004 & -0.001 & 0.004 & -0.001 & 0.004 & -0.001 & 0.004 & -0.001 & 0.004 \\
\hline Age & $-0.002 * *$ & 0.001 & $-0.002 * *$ & 0.001 & $-0.002 * *$ & 0.001 & $-0.002^{* *} *$ & 0.001 & $-0.002^{* *}$ & 0.001 & $-0.002 * *$ & 0.001 \\
\hline \multicolumn{13}{|l|}{ Model fit } \\
\hline $\mathrm{N}$ & \multicolumn{2}{|l|}{16266} & \multicolumn{2}{|l|}{7591} & \multicolumn{2}{|l|}{7591} & \multicolumn{2}{|l|}{7591} & \multicolumn{2}{|l|}{7591} & \multicolumn{2}{|l|}{7591} \\
\hline Wald-Chi $^{2}$ & \multicolumn{2}{|l|}{$26.87 * * *$} & \multicolumn{2}{|l|}{$78.03 * * *$} & \multicolumn{2}{|l|}{$80.21 * * *$} & \multicolumn{2}{|l|}{$93.36 * * *$} & \multicolumn{2}{|l|}{$82.11 * * *$} & \multicolumn{2}{|l|}{$95.44 * * *$} \\
\hline
\end{tabular}

All explanatory variables have been lagged by one year.

$* * * \mathrm{p}<0.001 * * \mathrm{p}<0.01 * \mathrm{p}<0.05^{\wedge} \mathrm{p}<0.1$.

The reported standard errors are computed through bootstrapping technique.

$\phi$ Family shareholding is measured as a percentage 
Table 5: Tobit Panel regressions on sample, time-period: 2005-2009

\begin{tabular}{|c|c|c|c|c|}
\hline & \multicolumn{2}{|c|}{ Full Model-Random effects } & \multicolumn{2}{|c|}{ Full Model-Fixed effects } \\
\hline & $\beta$-value & S.d & $\beta$-value & S.d \\
\hline \multicolumn{5}{|l|}{ Variables } \\
\hline \multicolumn{5}{|l|}{ Explanatory Variables } \\
\hline FAMILY & $-0.002 *$ & 0.001 & $-0.003 * *$ & 0.001 \\
\hline PSII & $-0.01 * *$ & 0.007 & $-0.027 *$ & 0.015 \\
\hline PRII-FII & $0.03 * * *$ & 0.005 & $0.001 *$ & 0.008 \\
\hline PRII-MF & $0.032 * * *$ & 0.008 & 0.006 & 0.011 \\
\hline \multicolumn{5}{|l|}{ Interactions } \\
\hline PSII*FAMILY & $-0.002 *$ & 0.001 & $-0.003^{\wedge}$ & 0.003 \\
\hline PRII-FII*FAMILY & $0.002 * *$ & 0.009 & $0.001 * * *$ & 0.002 \\
\hline PRII-MF*FAMILY & 0.003 & 0.001 & 0.006 & 0.002 \\
\hline \multicolumn{5}{|l|}{ Control Variables } \\
\hline BG_Aff & $0.952 * * *$ & 0.093 & & \\
\hline Board Size & $0.066^{* * * *}$ & 0.009 & 0.025 & 0.018 \\
\hline Board Independence & $0.307^{*}$ & 0.149 & 0.292 & 0.252 \\
\hline Exports & $0.015 * * *$ & 0.001 & $0.006 * *$ & 0.003 \\
\hline Lsize & 0.01 & 0.02 & $0.012 * * *$ & 0.01 \\
\hline $\mathrm{ROA}$ & $0.001 * * *$ & 0.02 & $0.03 * * *$ & 0.001 \\
\hline $\mathrm{DE}$ & -0.012 & 0.018 & 0.006 & 0.022 \\
\hline Age & -0.001 & 0.001 & -0.001 & 0.001 \\
\hline \multicolumn{5}{|l|}{ Model fit } \\
\hline $\mathrm{N}$ & \multicolumn{2}{|l|}{1815} & \multicolumn{2}{|l|}{1815} \\
\hline Wald-Chi $^{2}$ & \multicolumn{2}{|l|}{$872.9 * * *$} & \multicolumn{2}{|l|}{$167.9 * * *$} \\
\hline
\end{tabular}

All explanatory variables have been lagged by one year. Industry and year have been controlled for, but not reported. $* * * p<0.001 * * p<0.01 * p<0.05^{\wedge} \mathrm{p}<0$.

The reported standard errors are computed through bootstrapping technique.

Family shareholding is measured as a dummy variable for random effect regression and percentage for fixed effects regression. 
Table 6: Tobit Panel regressions on sample, time-period: 2010-2014

\begin{tabular}{|l|l|l|l|l|}
\hline & Full Model- Random effects & \multicolumn{2}{l|}{ Full Model- Fixed effects } \\
\hline & $\beta$-value & S.d & $\beta$-value & S.d \\
\hline Variables & & & & \\
\hline Explanatory Variables & & & & \\
\hline FAMILY & $-0.005^{*}$ & 0.002 & $-0.002^{*}$ & 0.006 \\
\hline PSII & $-0.01^{*}$ & 0.016 & $-0.04^{\wedge}$ & 0.033 \\
\hline PRII-FII & $0.009^{* *}$ & 0.009 & $0.029^{*}$ & 0.015 \\
\hline PRII-MF & $0.026^{* *}$ & 0.021 & $0.035^{*}$ & 0.027 \\
\hline Interactions & & & & \\
\hline PSII*FAMILY & -0.001 & 0.018 & -0.001 & 0.001 \\
\hline PRII-FII*FAMILY & $0.001^{* * *}$ & 0.002 & $0.001^{* * *}$ & 0.001 \\
\hline PRII-MF*FAMILY & 0.02 & 0.01 & 0.002 & 0.001 \\
\hline Control Variables & & & & \\
\hline BG_Aff & $0.119^{* * *}$ & 0.107 & & \\
\hline Board Size & $0.095^{* * *}$ & 0.01 & $0.049^{* * *}$ & 0.017 \\
\hline Board Independence & $0.333^{\wedge}$ & 0.179 & 0.193 & 0.243 \\
\hline Exports & $0.015^{* * *}$ & 0.001 & $0.003^{*}$ & 0.002 \\
\hline Lsize & 0.002 & 0.001 & $0.023^{*}$ & 0.014 \\
\hline ROA & $0.18^{* * *}$ & 0.001 & $0.1 *$ & 0.001 \\
\hline DE & -0.006 & 0.013 & -0.004 & 0.004 \\
\hline Age & 0.001 & 0.001 & 0.001 & 0.001 \\
\hline Model fit & & & & \\
\hline N & 5776 & & 5776 & \\
\hline Wald-Chi ${ }^{2}$ & $968^{* * *}$ & & $131.56^{* * *}$ & \\
\hline
\end{tabular}

All explanatory variables have been lagged by one year. Industry and year have been controlled for, but not reported. $* * * p<0.001 * * p<0.01 * p<0.05^{\wedge} \mathrm{p}<0$.

The reported standard errors are computed through bootstrapping technique.

Family shareholding is measured as a dummy variable for random effect regression and percentage for fixed effects regression. 
Table 7: Tobit Random effects regression on automobile and pharmaceutical companies, 2005-2014

\begin{tabular}{|l|l|l|}
\hline & \multicolumn{2}{|c|}{ Full model } \\
\hline & $\beta$-value & S.d \\
\hline Intercept & $-2.5^{* * *}$ & 0.35 \\
\hline Variables & & \\
\hline Explanatory Variables & & \\
\hline & & \\
\hline PSII & $-0.02^{* *}$ & 0.01 \\
\hline PRII-FII & $0.01^{*}$ & 0.06 \\
\hline PRII-MF & $0.01^{*}$ & 0.014 \\
\hline FAMILY & $-0.03^{*}$ & 0.02 \\
\hline Interactions & & \\
\hline PSII*FAMILY & $-0.001^{* * *}$ & 0.003 \\
\hline PRII-FII*FAMILY & $0.003^{\wedge}$ & 0.001 \\
\hline PRII-MF*FAMILY & 0.002 & 0.003 \\
\hline Control Variables & & \\
\hline BG_Aff & 0.003 & 0.13 \\
\hline Board Size & $0.04^{* *}$ & 0.01 \\
\hline Board Independence & -0.01 & 0.01 \\
\hline Exports & $0.005^{* * *}$ & 0.001 \\
\hline Lsize & $0.7^{* * *}$ & 0.3 \\
\hline ROA & $0.04^{\wedge}$ & 0.02 \\
\hline DE & -0.007 & 0.003 \\
\hline Age & $-0.01^{* *}$ & 0.03 \\
\hline Model fit & & \\
\hline N & 2234 & \\
\hline Wald-Chi & \\
\hline & $678.22^{* * *}$ & \\
\hline
\end{tabular}

All explanatory variables have been lagged by one year| Year has been controlled for, but not reported $* * * \mathrm{p}<0.001 * * \mathrm{p}<0.01 * \mathrm{p}<0.05 \wedge \mathrm{p}<0.1$

The reported standard errors are computed through bootstrapping technique 